Michael Plouffe*

\title{
Firm Heterogeneity and Trade-Policy Stances Evidence from a Survey of Japanese Producerst
}

\begin{abstract}
Recent research in international political economy has begun to explore the implications of producer heterogeneity for trade politics. Variations in productivity and size lead to systematic variations in market behaviors, especially with respect to firms' abilities to engage foreign markets. This heterogeneity similarly leads to systematic variations in policy stances: Highly productive firms are more likely to favor trade liberalization than their less productive counterparts. I test the role of firm heterogeneity on trade-policy stances using original and representative survey data of Japanese manufacturers. I find that highly productive firms are more likely to favor liberalization than others, while a large portion of producers is indifferent to trade-policy reform. Other producers do not know how they would be impacted by liberalization; these tend to be smaller than their counterparts. The relationship between productivity and pro-trade attitudes is robust, even when controlling for a wide range of internationalization modes.
\end{abstract}

\section{Introduction}

International trade has long been viewed as a source of domestic political conflict. While increasing trade leads to economic gains, these gains are not equally distributed among the members of a state's population. Trade's redistributional effects create clear winners and losers, and a large body of research in international political economy has been devoted to identifying these winners and losers and the ways in which they might impact potential trade-policy outcomes. ${ }^{1}$

\footnotetext{
*Corresponding author: Michael Plouffe, School of Public Policy, University College London, e-mail: michael.plouffe@ucl.ac.uk

$\dagger$ I thank Lawrence Broz, Peter Cowhey, Christina Davis, Stephan Haggard, Gordon Hanson, James Hollyer, Jason Kuo, Daniel Maliniak, Marc Muendler, Megumi Naoi, Chris O'Keefe, Iain Osgood, Ken Scheve, Neil Visalvanich, and several anonymous reviewers for insightful comments and suggestions. This research was supported in part by JSPS (A: Globalization and Domestic Politics). Earlier versions of this paper were presented at the 2011 meetings of the American Political Science Association and the International Political Economy Society.
}

1 Rogowski (1987); Grossman and Helpman (1994); Hiscox (2002). 
Within industries, heterogeneity in firm-level characteristics, such as size and productivity, has emerged as a robust determinant of producers' abilities to engage foreign markets. ${ }^{2}$ While most research has focused on exporting, other modes of internationalization-such as importing, offshoring, foreign direct investment (FDI) - follow similar patterns of engagement at the firm level. ${ }^{3}$ Large, highly productive producers can afford to participate in these activities, while their smaller and less efficient counterparts cannot. These differences in capabilities generate political divisions over trade policy within industries, where large and highly productive firms are more likely to seek liberalization than their counterparts.

I explore the implications of firm heterogeneity for trade-policy stances at the firm level. Most existing research on the producers and trade politics focuses on policy positions revealed through costly forms of political engagement. ${ }^{4}$ I use an original and representative survey of Japanese manufacturers to uncover patterns in latent policy stances. While industry characteristics, captured roughly by a series of comparative-advantage indicators, appear to affect policy stances, I find evidence of intra-industry divisions driven by the firm-specific characteristics fundamental to firm-heterogeneity studies. Highly productive firms are more likely to favor trade liberalization than their less-productive counterparts. Additionally, I uncover a large portion of firms where decision makers express no clear preference over trade-policy reform; these responses do not appear to be determined by firm heterogeneity. Finally, cases where respondents do not know the impact that trade liberalization would have on their business are not uncommon and are most frequently found among small producers.

\section{Trade Preferences in International Political Economy}

Trade-policy preferences have largely been studied at two levels in international political economy. Research on aggregated sector or factor-based cleavages has been complemented by a wide range of studies on sources of individual-level

2 Melitz (2003); Bernard et al. (2007a).

3 Bernard et al. (2012) provides an overview; see also Plouffe (2011); Tomiura et al. (2011); AbelKoch (2013b).

4 See, for example, Jensen et al. (2015); Kim (2016); Madeira (2013); Osgood (2016); Plouffe (2012); Plouffe (2015). 
trade preferences. ${ }^{5}$ Most work relies on predictions generated by the StolperSamuelson (factor) and Ricardo-Viner (sector) ideal-type models, while other efforts have sought to identify the varying levels of factor mobility that cause one configuration of preferences to dominate the other. ${ }^{6}$ Recent research has expanded upon these factor and sector-based models to incorporate a wide range of non-income sources for preferences. ${ }^{7}$

Over the past few years, attention has returned to the interests of producers in trade politics. Early research on this topic first uncovered the activation of firmbased attitudes from the decision makers responding to interviews, linking these to trade-policy demands. ${ }^{8}$ This has been complemented by work focusing on firms as important players in trade politics: Strong evidence points to multinationals seeking liberalization to improve their access to lucrative foreign markets, both in goods and services trade, ${ }^{9}$ as well as seeking protections for their investments abroad. ${ }^{10}$ Contrastingly, some producers seek protection, either through temporary trade barriers or subsidies. ${ }^{11}$ This protectionist stance has become the default policy position for research on producers and trade policy with the ubiquity of the 'Protection for Sale' framework, which has become the seminal framework for depicting producer engagement in trade politics. ${ }^{12}$ While this framework finds strong empirical support, ${ }^{13}$ particularly among comparative disadvantage (or import-competing) industries, ${ }^{14}$ accounting for variations among producers within industries has led to a range of valuable extensions to the original model, including the incorporation of include heterogeneous policy positions within industries. ${ }^{15}$ However, the focus on publicly-held trade-policy positions misses the underlying distribution of latent stances across firms, which are not as clearly defined as would be expected.

5 See, for example, Rogowski (1987); Alt and Gilligan (1994); Scheve and Slaughter (2001); Mayda and Rodrik (2005); Guisinger (2009); Blonigen (2011).

$6 \operatorname{Hiscox}(2001,2002)$.

7 See Hainmuller and Hiscox (2006); Mansfield and Mutz (2009); Naoi and Kume (2011); Kuo (2011); Roh and Tomz (2015).

8 Bauer et al. (1972).

9 Milner (1988); Woll (2008).

10 Kim et al. (2016); Johns and Wellhausen (2016).

11 Gilligan (1997); Alt et al. (1999).

12 Grossman and Helpman (1994).

13 Goldberg and Maggi (1999); Gawande and Bandyopadhyay (2000).

14 Gawande and Hoekman (2006).

15 Bombardini (2008); Bombardini and Trebbi (2012). For heterogeneous positions, see Abel-Koch (2013); Chang and Willmann (2006); Kim (2016). 


\section{Firms in International Markets}

The focus on micro-foundations in the study of international trade arose as a response to empirical deviations from new trade theory, leading to the development of 'new new trade' approaches incorporating variations at the plant or firm level. ${ }^{16}$ These theoretical models arose from empirical regularities that became apparent with the emergence and availability of increasingly detailed data: exporters are much larger, more productive, more capital intensive, and pay higher wages than non-exporters. ${ }^{17}$ Export engagement served as an early focal point for much interest in distinguishing between internationalizing producers and those only serving the domestic market. The latter group makes up the majority of firms: For example, only 18 percent of American manufacturers engage in exporting. ${ }^{18}$ Among these exporters, the intensive margin of export sales varies widely across industries; ${ }^{19}$ however, this is nothing compared to the high concentration of export sales among a small number of exporters. For example, in the United States, 1 percent of firms account for roughly 90 percent of trade by value, a figure that is similar to those observed in other countries. ${ }^{20}$ In the case of Japan, roughly 12 percent of Japanese manufacturers were multinationals, accounting for 94 percent of exports and 80 percent of imports. ${ }^{21}$

What is true of exporters also tends to be true of other internationalizing firms, such as those engaging in foreign direct investment (FDI), importing inputs, and offshore outsourcing, although the size and productivity premia associated with each these activities varies. ${ }^{22}$ The largest premia are associated with FDI, due to the particularly high costs of entry, while those associated with import entry are largely comparable to export premia. ${ }^{23}$ Ultimately, these variations in behaviors are attributed to total factor productivity (TFP), a scale-free measure of the efficiency with

16 Melitz (2003); Bernard et al. (2003).

17 See Bernard et al. (2007a) for a survey of the literature.

18 Bernard et al. (2007a), using data from the 2002 American Census of Manufactures.

19 Among American manufacturers, exports make up 7-21 percent of total shipments for export-

ers. Bernard et al. (2012).

20 Bernard et al. (2012).

21 These figures are from the 2000 round of a comprehensive survey of manufacturers described in Kiyota and Urata (2008).

22 See Helpman, Melitz and Yeaple (2004); Head and Ries (2003) for FDI; Kasahara and Lapham (2013); Şeker (2012); Plouffe (2011) for multiple internationalization strategies. Bernard et al. (2012) also discuss this.

23 Bernard et al. (2007a, 2012) provide an overview of these features; Tomiura examines them in Japan. Tables A2 and A3 in the appendix provide similar figures calculated from the survey data used here. 
which producers combine their inputs to produce final products. The more efficient a producer is, the more easily it can subsume costs. TFP correlates very highly with firm size, to the extent that the two are used interchangeably in models. ${ }^{24}$

The TFP and size premia between international firms and domestic firms is quite large. Among Japanese manufacturers, international firms are between 70 percent and nearly 400 percent larger than domestic manufacturers (depending on method of internationalization), while productivity premia typically range from 20 percent to 110 percet over domestic producers. ${ }^{25}$ Productivity distinctions between international and domestic producers remain after controlling for economies of scale as well as the available resource that accompany firm size. ${ }^{26}$

\section{Firms and Trade-Policy Stances}

A new generation of models of trade politics has emerged incorporating firm heterogeneity and its implications for trade engagement. ${ }^{27}$ In these models, firms are differentiated within industries by productivity, which determines firms' abilities to engage and compete in a variety of market-based activities. While high productivity allows firms to enter foreign markets, unproductive firms cannot. Accordingly, highly productive producers benefit from liberalization: Foreign markets offer profitable opportunities and liberalization reduces the operating costs associated with these markets. When foreign-market liberalization is accompanied by reciprocal actions, domestic producers face increased competition from foreign sources. This is particularly threatening for less productive domestic firms, as their reduced margins in the domestic market are not offset by the prospect of increased margins abroad. In the face of liberalization, the least productive firms may no longer find operating profitable and be forced to exit the market. While higher productivity firms also face increased import competition, their lower costs enable them to absorb these changes with relative ease. Consequently, these divergent experiences are used to predict variations in policy stances.

Prediction 1 - Highly productive firms are more likely to favor liberalization than less productive firms, even when controlling for current internationalization activities.

24 Melitz (2003); Head and Ries (2003); Tomiura (2007) provide empirical applications to Japanese firms.

25 Tomiura (2007), 119.

26 Bernard et al. (2007a), also Tomiura (2007).

27 Plouffe (2012, 2013); Kim (2016); Madeira (2013); Osgood (2016). 
The opportunities that highly productive firms face in foreign markets can be addressed through a wide range of internationalization modes, from engaging in trade, to direct investment in these markets. This menu of internationalization options offers costs and benefits that vary based on the type of activity and characteristics of the foreign market targeted. Reciprocal liberalization offers increased profit opportunities for internationalizing firms. For those with global or regional production chains, cost reductions from liberalization may be multiplied several times over, as a consequence of intra-firm trade. Indirect importers and exporters stand to benefit from reduced trade barriers both through reduced costs passed through from their intermediaries and the potential for some indirectly trading firms to take advantage of lower trade costs and begin to directly importing or exporting themselves.

Prediction 2 - Current internationalizing firms should be more likely to take a pro-liberalization stance than domestic producers.

These cleavages cut across those predicted by canonical models of trade politics, which generate trade-preference divisions based on factor abundance and industry-level export proclivity as depicted in Table 1.

The productivity-driven political cleavage predicted by firm-based models cuts across both those predicted by factor- and sector-based models. ${ }^{28}$ Firms are distributed by productivity within industries, resulting in intra-industry divisions over trade policy. Similarly, factors of production (such as skilled and unskilled labor) are employed by firms of all levels of productivity. Indeed, the fact that exporters employ a more-skilled workforce than domestic producers has been identified as a source of productivity differences. ${ }^{29}$

While firm-based preferences cut across industries, they are also shaped by industry characteristics that break down in ways familiar to political economists. In advanced economies, firms in comparative-advantage industries are more likely to view trade liberalization favorably than those in comparative-disadvantage industries as a result of their industry's proclivity towards exporting. ${ }^{30}$ For developing economies, this organization of industries breaks down in light of firm-level characteristics relating to traders. ${ }^{31}$ However, for developed economies, it matches neatly onto patterns of product differentiation within industries. ${ }^{32}$

28 Kim (2016); Osgood (2016); Plouffe (2013).

29 Yeaple (2005); Helpman et al. (2010).

30 Plouffe (2013).

31 Alvarez and Lopez (2005); Kim et al. (2016); Osgood et al. (2016).

32 Bernard et al. (2007b); Melitz and Ottaviano (2008). 
Table 1: Predicted Trade-Policy Cleavages

\begin{tabular}{llll}
\hline & Factor & Sector & Firm-Based \\
\hline Pro-Liberalization & Abundant Factor & Exporting Sector & High Productivity Firms \\
Pro-Protection & Scarce Factor & Importing Sector & Low Productivity Firms \\
\hline
\end{tabular}

Consequently, firms in comparative-advantage industries with highly differentiated products are more likely to benefit from export-market access than those in undifferentiated, or comparative-disadvantage, industries. ${ }^{33}$

Prediction 3 - Firms in comparative-advantage industries are more likely to support liberalization than those in comparative-disadvantage industries.

When considering the policy-stance divisions between firms, it is tempting to envision a clear divide between those favoring liberalization and those preferring protection. However, trade policy is a complex issue that often overlaps with other concerns. While existing research has largely focused on costly displays of tradepolicy stances, ${ }^{34}$ it is possible that these activities over-state the salience of the issue for non-participants. While these costly signals are readily observable, they may not accurately reflect the underlying distribution of policy positions. For many producers, trade policy may not be a salient issue. Its effects may seem to be indirect or less impactful than those of other policies, or its complexity inhibits the development of directional positions. For small producers in particular, tradepolicy stances should be less clear, as these firms are less likely to be able to allocate resources to understanding the effects of reform. ${ }^{35}$

Prediction 4 - A sizable portion of firms express no clear directional trade-policy stance, either because they expect no differing effect from liberalization or because they do not know how they would be affected. Small firms will be more likely to not know what to expect from trade.

The highly productive producers that benefit from foreign-market access tend to be large, possessing the resources necessary to forecast the impact of policy

33 Kim (2016); Osgood (2016).

34 Jensen, Quinn, and Weymouth (2015); Kim (2016); Madeira (2013); Osgood (2016); Plouffe (2012). Osgood et al. (2016) is a notable exception.

35 A similar argument can be found in the individual trade-policy preference literature: Guisinger (2009); Blonigen (2008, 2011). 
reforms. Smaller and less productive firms may not be able to engage in these activities, lacking the resources to devote to analyzing a wide range of policies. Consequently, even when decision makers at firms assess the impact of trade policy on their firm's business activities, they may not have a clear set of expectations aligning to existing theoretical predictions. While we expect highly productive firms to be more likely to favor liberalization than relatively unproductive firms, a large portion of producers expect no impact with a change in trade policy, while some firms simply have no clearly formed expectations of its impact.

\section{Internationalization Activities among Japanese Manufacturers}

In February 2011, Megumi Naoi, Arata Kuno, Ikuo Kume and I conducted an online survey of Japanese firm executives, seeking information on their expectations of globalization's effects on their firms. The survey was administered by Teikoku Data Bank, a highly regarded credit research company, ${ }^{36}$ whose database contains credit and financial information on 1.5 million Japanese firms. The survey was sent via email to all of the registered monitors in manufacturing and agriculture sectors, as well as five service industries. ${ }^{37}$ These monitors are firm executives and high-ranking employees; 4,183 were surveyed. In sum, 53 percent of the monitors responded, giving us a total of 2,217 responses. ${ }^{38}$ Nearly 1,400 of these are in the manufacturing sector. ${ }^{39}$

The survey's sampling frame was designed so that industries would be represented in the same proportions as in Japan's 2009 economic census; for industries with particularly high proportions of small and medium enterprises (SMEs), ${ }^{40}$ this entailed oversampling to ensure the distribution of respondents across industries would be largely comparable to the economic census. Figure 1 illustrates the distribution of respondents across industries as a proportion of all manufacturing

36 Teikoku Data Bank's website can be accessed at https://www.tdb.co.jp/english/.

37 The service industries are restaurants and bars, medical and welfare services, construction, temporary staff agencies, and entertainment. Only responses from the manufacturing sector are used in this study, as the underlying economic models are most directly applied to manufacturing industries.

38 Respondents were incentivized with a drawing for a subscription to Teikoku's services.

39 Table Al in the appendix provides descriptive statistics at the industry level.

40 For manufacturing, the Japanese government classifies a firm as an SME if its capital stock is less than $¥ 300$ million and/or has less than 300 employees. 


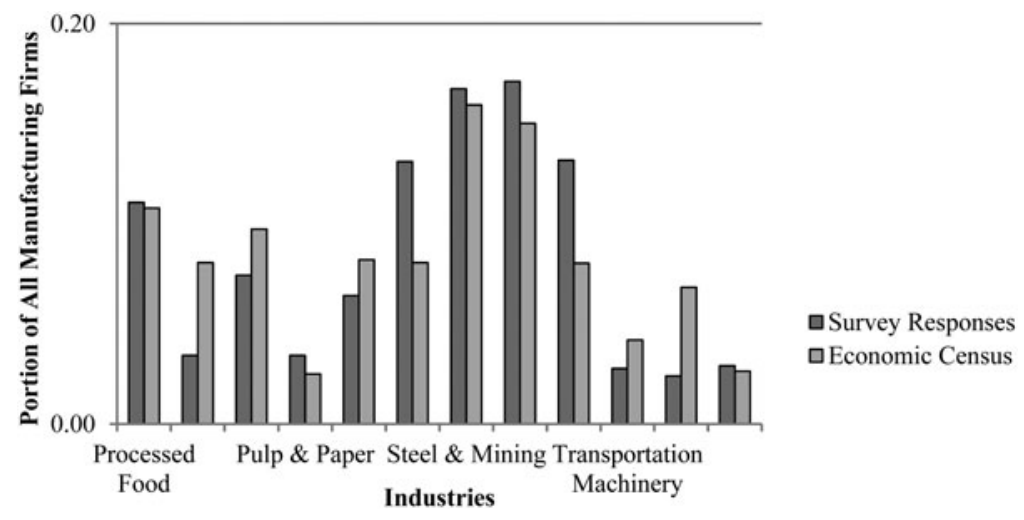

Figure 1: Firm Distribution across Industries of Survey Responses Compared to Economic Census

responses; these are compared to the distribution of firms across manufacturing industries in the economic census.

The overwhelming majority of respondents across all industries are SMEs, making up nearly 94 percent of firms across the manufacturing sector, closely following the composition of Japan's 2009 economic census. ${ }^{41}$ Across industries, the proportion of SME respondents very closely matches the proportion initially sampled (see Figure Al in the Appendix). In addition to closely matching the proportion of SMEs in the Japanese manufacturing sector, the distribution of firm sizes in terms of capital stock is closely representative of that for manufacturers in the economic census, as depicted in Figure 2. The composition of the survey sample fairly closely resembles the distribution of multi-establishment manufacturing enterprises from the economic census; very small single-establishment firms are underrepresented. This is not particularly surprising, as these firms are less likely to respond to the survey. Overall, the survey's capital-stock distribution approximates that of the economic census, exhibiting the characteristic long tail as size increases.

Foreign market engagement varies widely by industry, following commonly established patterns (Table A2 in the Appendix contains these data). As expected, trade engagement varies widely across manufacturing industries, with exporting twice as common in comparative-advantage industries as comparativedisadvantage industries (22 percent of firms to 10 percent of firms). This general pattern-greater internationalization engagement among comparative-advantage

41 According to the Japan Small Business Research Institute, this was around 99 percent. JSBRI (2010). 


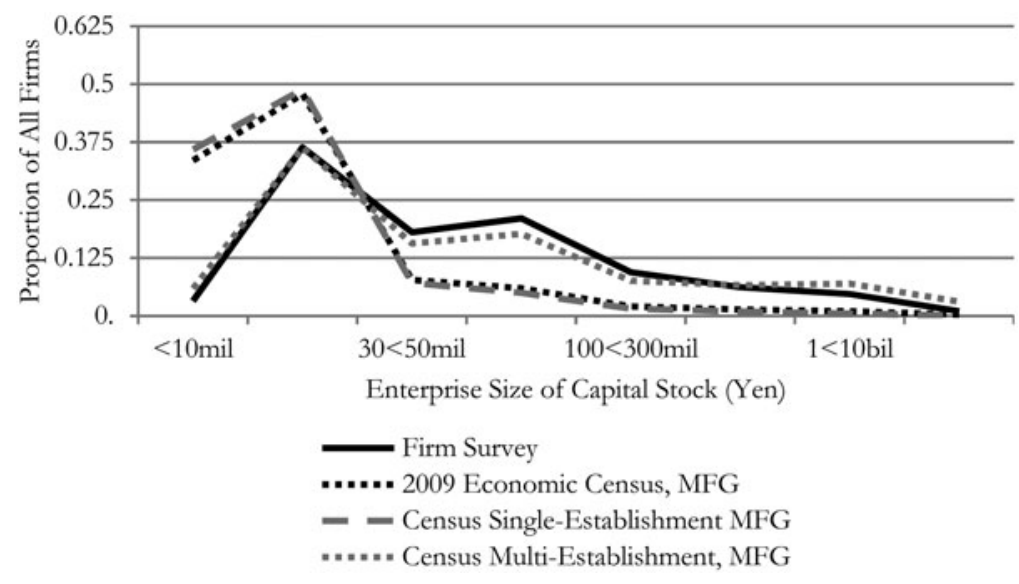

Figure 2: Firm-Distribution Representativeness

industries-holds across most forms of internationalization, although not necessarily to the same extent.

At the firm level, trading directly with foreign establishments is a rare activity; in our sample, nearly 18 percent of firms are direct exporters, while 25 percent are direct importers. Fifteen percent of firms are multinationals engaging in FDI, and 24 percent are active in offshore outsourcing. These figures are similar to those described by other studies of internationalization efforts by Japanese manufacturers using economic-census or comprehensive survey data. ${ }^{42}$

The fixed costs of trade, including the establishment of distribution networks, vary widely by the target market. ${ }^{43}$ Firms that cannot overcome these costs may engage a market through indirect forms of trade, in which third-party intermediaries (often multinationals or larger trading firms) provide use of their distribution networks. Consequently, the benefits and risks of intermediated trade are shared between producers and intermediaries, while the fixed costs of market entry are significantly reduced for producers engaging these intermediaries. Both indirect exporting and importing are more common than their direct counterparts, as these methods of internationalization are employed by 24 percent and 44 percent of firms, respectively. There is some overlap with direct traders, as 8.5 percent of firms are both direct and indirect exporters, while 9.5 percent are direct and indirect importers. Over 52 percent of firms in comparative-disadvantage industries

42 For example, see Kimura and Kiyota (2006); Kiyota and Urata (2008); Tomiura et al. (2011); Wakasugi and Tanaka (2012).

43 Bernard et al. (2015), explore this in greater detail. 
Table 2: Multiple Forms of Internationalization, Percent of Respondents

\begin{tabular}{lrrrrrr}
\hline & $\begin{array}{r}\text { Indirect } \\
\text { Export }\end{array}$ & $\begin{array}{r}\text { Indirect } \\
\text { Import }\end{array}$ & $\begin{array}{r}\text { Direct } \\
\text { Export }\end{array}$ & $\begin{array}{r}\text { Direct } \\
\text { Import }\end{array}$ & FDI & Offshore \\
\hline I. Export & $3.6 \%$ & & & & & \\
I. Import & $12.8 \%$ & $18.7 \%$ & & & & \\
D. Export & $8.5 \%$ & $8.9 \%$ & $1.0 \%$ & & & \\
D. Import & $10.2 \%$ & $9.5 \%$ & $11.1 \%$ & $1.8 \%$ & & \\
FDI & $6.6 \%$ & $7.9 \%$ & $6.4 \%$ & $9.7 \%$ & $0.9 \%$ & \\
Offshore & $8.4 \%$ & $13.0 \%$ & $6.6 \%$ & $13.6 \%$ & $7.1 \%$ & $1.4 \%$ \\
\hline
\end{tabular}

indirectly import raw materials, intermediate inputs, or finished products. This provides evidence that a large portion of producers in these industries benefit from open trade, counter to Ricardo-Viner expectations.

The characteristics of internationalizing firms compared to those of domestic firms largely align with established patterns. ${ }^{44}$ Firms that engage foreign markets are larger, more capital intensive and more productive than domestic firms. The one notable and regular exception to this is offshore outsourcing and capital intensity: It is well established that offshoring firms are less capital-intensive than their counterparts. ${ }^{45}$

It is important to note that these different forms of internationalization are not mutually exclusive. As demonstrated in Table 2, a number of firms employ multiple methods of engaging foreign markets. The diagonal indicates the percent of firms that only engage foreign markets in the specified manner. With the exception of indirect importing, which accounts for nearly 19 percent of all respondents, it is far more common for internationalizing firms to participate in multiple forms of engagement. Participation rates for single modes of internationalization indirectly reflect the fixed costs associated with each method of entry. For example, most multinationals that engage in FDI to at least one foreign market should be able to absorb costs associated with other forms of internationalization more easily; the modes of engagement they choose will depend on the structure of costs associated with each. As a case in point, 23 percent of multinationals also engage in both direct and indirect exporting; nearly 33 percent are direct two-way traders.

These descriptive figures highlight the wide variety of market behaviors among Japanese manufacturers. They also serve to demonstrate the representativeness of these features of our survey data when compared to analyses of economic-census

44 Details can be found in Tables A3 and A4 in the Appendix. Table A5 presents correlation coefficients between internationalization modes.

45 Tomiura et al. (2011); Bernard et al. (2012). 
data and comprehensive surveys of Japanese producers. These forms of international engagement are additionally broadly similar to levels economic integration among other advanced economies. ${ }^{46}$ The divisions between firms that possess the capabilities to participate in these modes of internationalization and those that do not, serve as the foundation for a firm-based approach to trade politics.

\section{Trade-Policy Stances and Heterogeneous Firms}

Just as trade and other forms of foreign-market engagement vary significantly within industries, so too do trade-policy stances. Two questions from our survey capture firm decision-makers' expectations regarding the prospective impact of liberalizing trade-policy reforms on future business activities. The questions are framed in a prospective (rather than retrospective) manner to lead respondents to base their answer on forward-looking forecasts, rather than reflecting on previous experiences with liberalization. The effect is to shift attention away from revealed preferences towards the impact of information availability for business executives in the policy-making environment. ${ }^{47}$ Additionally, this avoids issue linkages and framing effects from previous debates. Consequently, this creates a more focused environment for examining expectations of trade-policy's impact on future business.

The respondents were specifically directed to answer questions with respect to the impact on their business and to avoid responses based on personal ideological or political views. Established evidence shows that, when questions are framed in this manner, individuals will react positively to the framing, even when employerspecific impacts would contradict personal preferences or ideologies. ${ }^{48}$

The survey instruments regarding trade-policy stance are included alongside a list of other policy questions. ${ }^{49}$ The questions are framed as follows:

'Please tell us how the following changes would affect your business. In answering these questions, please answer strictly in terms of impact on your business, rather than providing your personal opinions.

46 Bernard et al. (2007a); Bernard et al. (2012); Hayakawa et al. (2012).

47 Nadeau et al. (1999); Kuno and Naoi (2015).

48 Bauer, de Sola Poole, and Dexter (1972).

49 These two questions are placed before similar questions relating to more specific policies, such as the Trans-Pacific Partnership. Questions regarding market behaviors, such as trade engagement, were placed at the end of the survey. 
The expansion and liberalization of imports of manufactured goods.

The deregulation and liberalization of foreign export markets.

Respondents could choose one answer in response to each question, with five available responses:

Positive effects; Negative effects; No impact; Depends on division within the firm; Don't know.

The framing device targets the resulting responses to focus on the firm, ${ }^{50}$ and on the face of things, responses tend to follow expected patterns. Export-market liberalization is much more likely to be seen as beneficial in comparative-advantage industries (38 percent of responses, compared to 22 percent in comparative-disadvantage industries). The prospect of import liberalization appears to be viewed negatively at much more similar rates across comparative-advantage industries and comparative-disadvantage industries (18 percent of responses compared 22 percent; the difference is statistically insignificant).

The responses similarly lend evidence to the importance of the differences in firms' characteristics and behaviors within industries. Fear of trade liberalization appears to be overstated in the literature: In no industry did more than 26 percent of firms view import liberalization as having negative effects on their business. Positive responses to import liberalization range between 5 percent and 28 percent of firms, while the plurality of respondents does not expect their activities to be significantly impacted by a reduction in trade barriers. It is possible that variability in responses to the import-liberalization question could be attributed in part to its potentially vague interpretation. Imports to one firm could represent opportunity for accessing raw materials or intermediate inputs; to another firm, these may represent competition from foreign producers.

Figure 3 illustrates the breakdown of trade-policy stances by firm size. While models of firm heterogeneity and market behaviors emphasize the importance of TFP, this fundamental characteristic cannot be measured directly. Instead, it is frequently estimated with the assistance of proxy measures or indirect estimation routines. Productivity estimators range from simple linear predictors that approximate a production function ${ }^{51}$ to systems of equations that correct for sources of bias inherent in simpler estimators. ${ }^{52}$ Alternatively, observable firm-level characteristics that are known to correlate highly with TFP are employed as direct proxies.

50 See Bauer, de Sola Poole, and Dexter (1972).

51 See Head and Ries (2003); Tomiura (2007).

52 Wooldridge (2009) provides an overview of these approaches. 


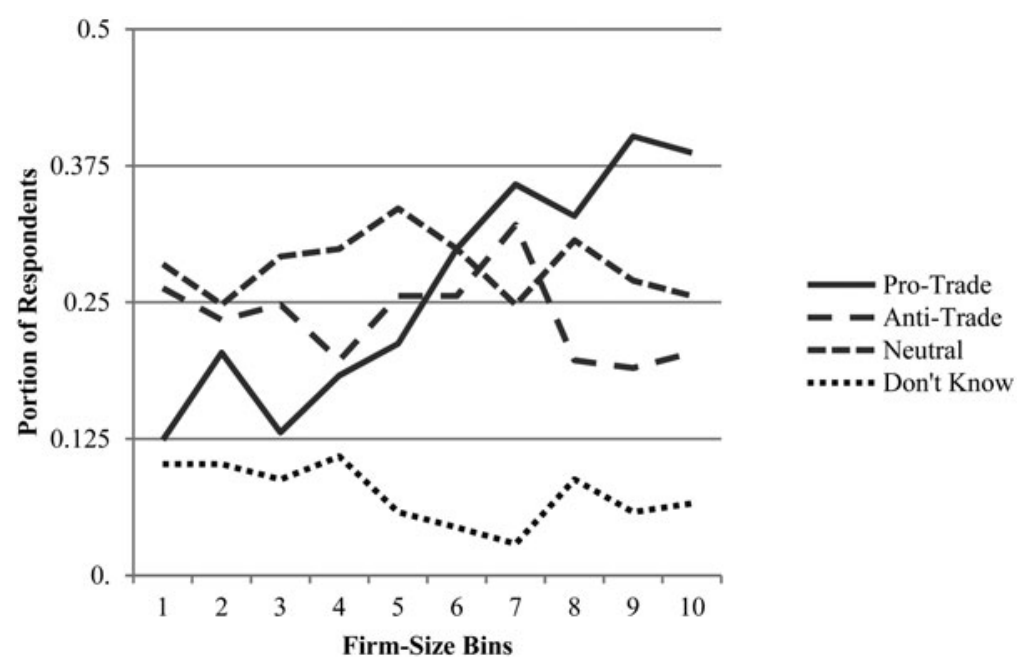

Figure 3: Respondents' Trade-Policy Positions by Firm Size

The most obvious candidate in this role is firm-level revenues or net sales, due to the high empirical correlation and theoretical link between the two. ${ }^{53}$ This fact is particularly useful in the case of cross-sectional data, where the lack of repeated observations precludes the use of sophisticated estimators. ${ }^{54}$ In Figure 3, log-transformed sales have been divided into ten bins of equal size. ${ }^{55}$

To capture directional policy stances, I created a binary index, trade stance. Conceptually, trade stance indicates when respondents expect export or import liberalization to benefit (or harm) their firm. Trade stance takes a pro-trade value (one) when import (or export) liberalization is linked to positive benefits, and export (or import) liberalization is associated with positive, neutral, or variable (depends on division) influences. ${ }^{56}$ The index takes an anti-trade value (zero) when import (or export) liberalization is tied to a negative impact, and export

53 See Head and Ries (2003) for an example of the former and Melitz (2003) for the latter.

54 An earlier version of this study employed a linear TFP estimator; however, because it does not exhibit a number of expected attributes without substantial changes to the functional form, I rely instead on firm size as the preferred TFP proxy.

55 Bin size is 137 firms, with three bins containing 138 firms.

56 The average respondent for 'variable impact' is larger and more likely to engage foreign markets than other firms. This accords with the empirical research on multi-establishment and multi-product firms and trade: these firms tend to be larger and more productive than singleproduct producers. 
(or import) liberalization is connected to negative, neutral, or variable (depends on division) effects. While the probability of anti-trade stance slightly negatively correlated with firm size, likelihood of pro-trade stance increases considerably with firm size.

A large proportion of responses indicate that trade-policy reform would have no expected impact on future business interests. This is somewhat unanticipated by theory: Ricardo-Viner would predict sharp comparative-advantage-based cleavages, while firm-based theories similarly leave little room for non-directional stances. These responses make up roughly 29 percent of all responses. While bin four has the highest level of 'no impact' responses, there does not appear to be any relationship between firm size and the propensity to expect 'no impact' from trade liberalization. The prevalence of these 'no impact' stances across the distribution of firms potentially indicates a lack of trade-policy salience across the full range of producers. For many firms focused on the domestic market alone, trade policy may only be viewed as having indirect effects on business activities. Decisions may then be made in response to, or in anticipation of, those trends with a direct influence on business.

'No impact' responses may also be driven by imperfect information. Trade policy is a complex issue and a single reform can have multifarious impacts at the level of the individual firm. Combined with a fairly low salience, information may be viewed as costly, particularly given the range of alternative targets for investment of resources. Finally, the mutual 'don't know' responses, which, while generally rare, are more common for smaller and less productive firms than their larger and more productive counterparts. This provides some evidence supporting the argument that costly information regarding trade policy's impacts creates a barrier for producers with fewer resources to gain a sense of how they may be affected by impending trade reform.

Table 3 presents some basic insight on the influence of firm heterogeneity in the formation of trade-policy stances. Models 1-3 present logit regressions with three proxies for comparative advantage. Trade balance is a simple binary indicator of comparative advantage operationalized using the average industry-level trade balance over the previous three years; ${ }^{57}$ while this approach is clearly problematic, it provides a simple approach to capturing an industry's trade orientation and correlates highly with the other proxies. ${ }^{58} R C A$ is a standardized measure of revealed comparative advantage, calculated through WITS and based on industry-level

57 Industry-level trade data come from World Integrated Trade Solution (WITS), at http://wits. worldbank.org/.

58 The correlation coefficients with RCA and Skilled Labor are 0.82 and 0.66 , respectively. 
Table 3: Industry and Firm Effects on Reciprocal Trade Stance

\begin{tabular}{|c|c|c|c|c|c|}
\hline & & Model 1 & Model 2 & Model 3 & Model 4 \\
\hline \multirow{14}{*}{$\begin{array}{l}\text { Comparative-Advant-age } \\
\text { Proxies }\end{array}$} & Trade & $1.499 * \star \star$ & & & \\
\hline & Balance & & & & \\
\hline & & $(0.187)$ & & & \\
\hline & RCA & & $1.269^{\star \star \star}$ & & \\
\hline & Skilled Labor & & & $1.265^{\star \star \star}$ & \multirow{6}{*}{$\begin{array}{r}1.280^{\star \star \star} \\
(0.056)\end{array}$} \\
\hline & & & & $(0.032)$ & \\
\hline & Firm Size & $1.284^{\star \star \star}$ & $1.289^{\star \star \star}$ & $1.293^{\star \star \star}$ & \\
\hline & & (0.055) & $(0.057)$ & $(0.057)$ & \\
\hline & Constant & $0.129 * \star \star$ & $0.163^{\star \star \star}$ & $0.159^{\star \star \star}$ & \\
\hline & & $(0.040)$ & $(0.053)$ & $(0.054)$ & \\
\hline & Observations & 684 & 684 & 684 & 684 \\
\hline & Pseudo- $\mathrm{R}^{2}$ & 0.030 & 0.033 & 0.034 & 0.023 \\
\hline & Wald $\mathrm{Chi}^{2}$ & 40.20 & 49.01 & 125.80 & 32.27 \\
\hline & $\mathrm{AIC}$ & 923.87 & 920.76 & 920.53 & 862.89 \\
\hline
\end{tabular}

$\star \star \star ~ p<0.01 * \star p ~<0.05 * \mathrm{p}<0.1$

Logit regressions and conditional logit run with heteroskedastically robust standard errors clustered at the industry level, with odds ratios reported.

data from 2010. The final proxy for comparative advantage, skilled labor, consists of the standardized skilled-labor portion of employment in each industry. ${ }^{59}$ In each of these models, an industry's comparative-advantage orientation is associated with increased likelihood of firms taking a pro-trade stance. Model 4 is a conditional logit, with each industry forming a separate group; the odds ratio for firm size remains roughly the same as in the previous models. Importantly for firm-based models of trade politics, firm size, measured as the natural logarithm of net sales, is positively associated with pro-trade stances, an effect that remains consistent across the different measures of comparative advantage. Keeping in mind the fact that firm size is a proxy for TFP, higher productivity producers are more likely than their low-productivity counterparts to favor trade liberalization.

While these results provide some preliminary evidence of the relationship between firm size and trade stance, both foreign-market engagement and exposure are missing from the models. These are presented in Table 4. As demonstrated in the previous section, participation in global markets varies widely across firms and

59 Disaggregated industry-level employment data are sourced from the Japanese Statistics Bureau at http://www.stat.go.jp/english/data/index.htm. 
Table 4: Internationalization Activities and Reciprocal Trade Stances

\begin{tabular}{|c|c|c|c|}
\hline & Model 5 & Model 6 & Model 7 \\
\hline Firm Size & $\begin{array}{r}1.118^{\star \star} \\
(0.055)\end{array}$ & $\begin{array}{r}1.152^{\star \star \star} \\
(0.050)\end{array}$ & $\begin{array}{r}1.108^{\star \star} \\
(0.057)\end{array}$ \\
\hline RCA & $\begin{array}{r}1.158^{\star \star \star} \\
(0.042)\end{array}$ & $\begin{array}{r}1.228^{\star \star \star} \\
(0.053)\end{array}$ & \\
\hline Direct Exporter & $\begin{array}{r}1.046 \\
(0.287)\end{array}$ & $\begin{array}{r}1.076 \\
(0.301)\end{array}$ & $\begin{array}{r}1.050 \\
(0.290)\end{array}$ \\
\hline Direct Importer & $\begin{array}{c}1.999 \star \star \\
(0.624)\end{array}$ & $\begin{array}{r}2.274^{\star \star \star} \\
(0.398)\end{array}$ & $\begin{array}{r}2.000^{\star \star} \\
(0.623)\end{array}$ \\
\hline FDI & $\begin{array}{r}1.486 \\
(0.480)\end{array}$ & & $\begin{array}{r}1.457 \\
(0.469)\end{array}$ \\
\hline Offshoring & $\begin{array}{r}1.124 \\
(0.267)\end{array}$ & & $\begin{array}{r}1.128 \\
(0.272)\end{array}$ \\
\hline Indirect Exporter & $\begin{array}{r}1.767^{\star \star \star} \\
(0.225)\end{array}$ & $\begin{array}{r}1.785^{\star \star \star} \\
(0.221)\end{array}$ & $\begin{array}{r}1.786^{\star \star} \\
(0.228)\end{array}$ \\
\hline Indirect Importer & $\begin{array}{r}1.145 \\
(0.176)\end{array}$ & $\begin{array}{r}1.155 \\
(0.174)\end{array}$ & $\begin{array}{r}1.119 \\
(0.178)\end{array}$ \\
\hline Industry Imports & & $\begin{array}{r}1.020 \\
(0.014)\end{array}$ & \\
\hline AWT & & $\begin{array}{l}1.029^{\star} \\
(0.015)\end{array}$ & \\
\hline Constant & $\begin{array}{r}0.273^{\star \star \star} \\
(0.092)\end{array}$ & $\begin{array}{r}0.157^{\star \star \star} \\
(0.047)\end{array}$ & \\
\hline Observations & 684 & 684 & 684 \\
\hline Pseudo- $R^{2}$ & 0.077 & 0.074 & 0.070 \\
\hline Wald $\mathrm{Chi}^{2}$ & 1332.5 & 381.20 & 54.05 \\
\hline AIC & 891.46 & 894.24 & 876.20 \\
\hline
\end{tabular}

$\star \star \star ~ p<0.01 * \star p<0.05 * p<0.1$

Models 4 and 5 are logit regressions; Model 6 is a conditional logit. All models are run with heteroskedastically robust standard errors clustered at the industry level, and odds ratios reported.

industries. Internationalizing firms, whether traders or direct investors, are intuitively likely to favor economic integration, as this would reduce costs of overseas business. When directly specifying engagement in these activities (Model 5), the effects of firm size and $R C A$ remain positive and in the expected direction. ${ }^{60}$ Among forms of international-market engagement, all coefficients are positive, although significance is

60 Several similar models are presented in the Appendix, with similar results. 
only reached by direct importing and indirect exporting. ${ }^{61}$ Comparable results are found when $R C A$ is substituted for skilled labor or trade balance.

In addition to firm-level engagement with foreign markets, industry-level access may impact trade stance. Model 6 incorporates measures of averageweighted import tariffs $(A W T)$ and logged industry-level imports (Industry Imports). Both measures are 2007-2009 averages calculated from industry-level WITS data. Industry-level exports are omitted, as this term correlates very highly with each of the comparative-advantage proxies. ${ }^{62}$ Industry imports is not significantly linked to pro-trade stances, while $A W T$ exhibits a weakly significant positive effect. ${ }^{63}$ However, as Table A10 in the Appendix demonstrates, the relationship between both industry imports and $A W T$ is not robust across specifications using different comparative-advantage proxies. The impact of firm size on protrade stances is consistent and significant across all specifications. Model 7 presents the results of a conditional logit, with firms grouped by industry; results are consistent with those of the previous models.

To verify the robustness of reciprocal-trade preference results in Table 4, I replicated the models with export-liberalization stances presented in Table 5. While most trade policy is conducted on a reciprocal basis-either through multilateral means or bilateral agreements-a simple test of export-liberalization stances captures the opportunities available to highly productive firms without the potentially complicating interpretation of import liberalization as applying to import competition or imported inputs. The significant positive relationship between firm size and pro-liberalization stances remains. Indirect exporters are much more likely than other firms to favor export-market liberalization, unsurprising given the likely status of many as potential direct exporters in the face of lower trade barriers. On its face, it is surprising that direct importers are so strongly linked to export-market liberalization. However, nearly 44 percent of direct importers are also direct exporters; likewise, many of the firms holding favorable export-market liberalization stances also view import liberalization favorably. Industry-level characteristics are only significant in Model 9, where RCA is included alongside industry-wide imports and $A W T$, but the effects are in the expected direction, with firms in comparative-advantage industries more likely to hold pro-liberalization attitudes.

61 Significance for these terms varies if partial internationalization menus are included in the model; however, firm size and RCA remain positive and significant. Additional specifications can be found in the appendix.

62 Depending on the measure, the correlation coefficient varies between 0.80 and 0.88 .

$63 A W T$ for export markets does not appear to be linked to trade stance and risks introducing issues with two of the comparative-advantage proxies. 
Table 5: Internationalization Activities and Export-Market Liberalization Stances

\begin{tabular}{|c|c|c|c|}
\hline & Model 8 & Model 9 & Model 10 \\
\hline \multirow[t]{2}{*}{ Firm Size } & 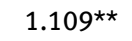 & $1.102^{\star \star \star}$ & $1.081^{\star \star}$ \\
\hline & $(0.040)$ & $(0.037)$ & $(0.039)$ \\
\hline \multirow[t]{2}{*}{ RCA } & 1.115 & $1.223^{\star \star \star}$ & \\
\hline & $(0.080)$ & $(0.060)$ & \\
\hline \multirow[t]{2}{*}{ Direct Exporter } & 1.448 & 1.477 & 1.476 \\
\hline & $(0.484)$ & $(0.497)$ & $(0.482)$ \\
\hline \multirow[t]{2}{*}{ Direct Importer } & $2.010^{\star \star}$ & $2.210^{\star \star \star}$ & $1.952^{\star}$ \\
\hline & $(0.694)$ & (0.492) & $(0.679)$ \\
\hline \multirow[t]{2}{*}{ FDI } & 1.157 & & 1.157 \\
\hline & $(0.307)$ & & $(0.312)$ \\
\hline \multirow[t]{2}{*}{ Offshoring } & 1.159 & & 1.166 \\
\hline & $(0.307)$ & & $(0.315)$ \\
\hline \multirow[t]{2}{*}{ Indirect Exporter } & $2.388^{\star \star \star}$ & $2.402^{\star \star \star}$ & $2.303^{\star \star \star}$ \\
\hline & $(0.283)$ & $(0.279)$ & $(0.256)$ \\
\hline \multirow[t]{2}{*}{ Indirect Importer } & 1.162 & 1.149 & 1.090 \\
\hline & $(0.131)$ & $(0.129)$ & $(0.133)$ \\
\hline \multirow[t]{2}{*}{ Industry Imports } & & 1.061 & \\
\hline & & $(0.050)$ & \\
\hline \multirow[t]{2}{*}{ AWT } & & $1.088^{\star \star \star}$ & \\
\hline & & $(0.032)$ & \\
\hline \multirow[t]{2}{*}{ Constant } & $0.309 * \star \star$ & $0.095^{\star \star \star}$ & \\
\hline & $(0.078)$ & $(0.081)$ & \\
\hline Observations & 628 & 628 & 628 \\
\hline Pseudo- $R^{2}$ & 0.095 & 0.099 & 0.084 \\
\hline Wald $\mathrm{Chi}^{2}$ & 248.98 & 332.85 & 168.31 \\
\hline AIC & 802.62 & 799.75 & 742.06 \\
\hline
\end{tabular}

$\star \star \star ~ p<0.01 * \star p<0.05 * p<0.1$

Models 8 and 9 are logit regressions; Model 10 is a conditional logit. All models are run with heteroskedastically robust standard errors clustered at the industry level, and odds ratios reported.

My final tests return to the set of responses to the trade-policy position question as illustrated in Figure 3. Table 6 presents these in two ways, reporting average marginal effects (AMEs). ${ }^{64}$ Model 11 is an ordered logit, where 'no impact' stances have been added as an intermediate level to the original trade-stance variable, creating a three-outcome set of responses. The results here largely mirror those from

64 AME is the averaged value of the marginal effect for a covariate calculated across all observations. 


\begin{tabular}{|c|c|c|c|c|c|c|c|}
\hline \multicolumn{8}{|c|}{ Table 6: Trade Stances with Multiple Outcomes } \\
\hline & \multicolumn{3}{|c|}{ Model 11 (Ordered Logit) } & \multicolumn{4}{|c|}{ Model 12 (Multinomial Logit) } \\
\hline & Anti-Trade & No Impact & Pro-Trade & Don’t Know & Anti-Trade & No Impact & Pro-Trade \\
\hline Firm Size & $\begin{array}{c}-0.014^{\star} \\
(0.008)\end{array}$ & $\begin{array}{c}-6.87 \times 10^{-4} \\
\left(5.22 \times 10^{-4}\right)\end{array}$ & $\begin{array}{l}0.014^{\star} \\
(0.008)\end{array}$ & $\begin{array}{r}-0.008^{\star \star} \\
(0.004)\end{array}$ & $\begin{array}{r}-0.012 \\
(0.011)\end{array}$ & $\begin{array}{r}0.008 \\
(0.011)\end{array}$ & $\begin{array}{l}0.012^{\star} \\
(0.007)\end{array}$ \\
\hline RCA & $\begin{array}{c}-0.014^{\star \star} \\
(0.006)\end{array}$ & $\begin{array}{r}-6.83 \times 10^{-4 \star \star} \\
\left(3.22 \times 10^{-4}\right)\end{array}$ & $\begin{array}{r}0.014^{\star \star} \\
(0.006)\end{array}$ & $\begin{array}{r}0.006 \\
(0.007)\end{array}$ & $\begin{array}{l}-0.014 \\
(0.016)\end{array}$ & $\begin{array}{r}-0.011 \\
(0.022)\end{array}$ & $\begin{array}{r}0.019 \\
(0.012)\end{array}$ \\
\hline \multirow[t]{2}{*}{ Dir Exporter } & -0.014 & $-9.56 \times 10^{-4}$ & 0.015 & -0.025 & 0.030 & -0.046 & 0.042 \\
\hline & $(0.043)$ & $(0.004)$ & $(0.047)$ & $(0.017)$ & $(0.041)$ & $(0.031)$ & $(0.049)$ \\
\hline Dir Importer & $\begin{array}{c}-0.098^{\star \star} \\
(0.048)\end{array}$ & $\begin{array}{l}-0.016 \\
(0.013)\end{array}$ & $\begin{array}{l}0.114^{\star} \\
(0.061)\end{array}$ & $\begin{array}{l}-0.009 \\
(0.014)\end{array}$ & $\begin{array}{r}-0.088^{\star \star} \\
(0.040)\end{array}$ & $\begin{array}{l}-0.001 \\
(0.036)\end{array}$ & $\begin{array}{l}0.098^{\star} \\
(0.055)\end{array}$ \\
\hline \multirow[t]{2}{*}{ FDI } & $-0.092^{\star \star}$ & -0.018 & $0.110^{\star \star}$ & 0.036 & -0.014 & $-0.133^{\star \star \star}$ & $0.110^{\star *}$ \\
\hline & $(0.041)$ & $(0.015)$ & $(0.055)$ & $(0.036)$ & $(0.059)$ & $(0.036)$ & $(0.043)$ \\
\hline \multirow[t]{2}{*}{ Offshoring } & -0.022 & -0.002 & 0.024 & -0.018 & 0.011 & $-0.046^{\star \star}$ & 0.054 \\
\hline & $(0.038)$ & $(0.004)$ & $(0.041)$ & $(0.014)$ & $(0.043)$ & $(0.022)$ & $(0.036)$ \\
\hline \multirow[t]{2}{*}{ Ind Exporter } & $-0.104^{\star \star \star}$ & $-0.018^{\star \star \star}$ & $0.122^{\star \star \star}$ & $-0.047^{\star \star \star *}$ & -0.005 & $-0.119^{\star \star \star}$ & $0.171^{\star \star \star}$ \\
\hline & $(0.017)$ & $(0.006)$ & $(0.023)$ & $(0.016)$ & $(0.027)$ & $(0.023)$ & (0.019) \\
\hline \multirow[t]{2}{*}{ Ind Importer } & -0.016 & -0.001 & 0.016 & -0.014 & 0.021 & $-0.056^{\star}$ & $0.049^{\star \star}$ \\
\hline & $(0.022)$ & $(0.001)$ & $(0.024)$ & $(0.014)$ & $(0.031)$ & (0.033) & $(0.020)$ \\
\hline \multicolumn{2}{|l|}{ Observations } & \multicolumn{2}{|l|}{1,071} & \multicolumn{4}{|c|}{1,173} \\
\hline \multicolumn{2}{|l|}{ Pseudo- $R^{2}$} & 0.038 & & \multicolumn{4}{|c|}{0.052} \\
\hline \multicolumn{2}{|l|}{ AIC } & \multicolumn{2}{|l|}{$2,278.17$} & \multicolumn{4}{|c|}{$2,905.41$} \\
\hline
\end{tabular}

$\star * \star \mathrm{p}<0.01 * \star \mathrm{p}<0.05 * \mathrm{p}<0.1$

Both models run with heteroskedastically robust standard errors clustered at the industry level, with average marginal effects reported. 
the previous models. As expected, firm size is negatively associated with anti-trade stances and positively linked to pro-trade stances, although significance is reduced. $R C A$ is significant and its coefficient is negatively signed for both antitrade and 'no impact' stances, while positively signed for pro-trade stances. This corresponds with theoretical predictions on both counts: Pro-trade stances are more likely among large and productive firms and in comparative-advantage industries. The sign on $R C A$ for 'no impact' stances seems to indicate the divide over trade policy is more readily apparent in comparative-advantage industries, where reallocations in response to liberalization are relatively large. Among internationalization options, effects are largely comparable to those of previous models. Unsurprisingly, direct importers are more likely to favor liberalization than other firms. Indirect exporters are more likely to favor liberalization than take protectionist or neutral stances; this is likely either driven by their sensitivity to demand fluctuations among exporting buyers or the potential opportunity to export directly in the event of reduced trade barriers. One difference that emerges is that firms engaging in FDI are much more likely to take pro-trade stances than anti-trade stances, pointing to the importance of international supply chains.

Model 12 incorporates 'don't know' responses in addition to the trade-policy stances in Model 11, and is estimated as a multinomial logit, with anti-trade stance as the baseline category. ${ }^{65}$ Firm size remains positively linked to pro-trade stances, while 'don't know' responses are associated with smaller firms. The latter result is unsurprising as smaller firms are more likely to lack resources to assess the impact of trade liberalization on their prospects. The range of internationalization methods largely follows the same pattern as in previous models. In general, firms serving foreign markets are more likely to take pro-trade stances and less likely to respond that they 'don't know' trade policy's impact on their activities.

Across a range of specifications, TFP and comparative advantage, proxied through firm size and RCA respectively, exhibit a positive impact on the prospect that firms will take pro-trade stances (Predictions 1 and 3). Engagement with foreign markets is sometimes linked with a positive effect on pro-trade stances, particularly for direct importers and indirect exporters (Prediction 2). For other forms of engagement, coefficients are generally signed in the expected direction, but are infrequently significant. This is most likely due to the fact that the survey questions on these activities did not capture variation on the intensive margin of these behaviors: Marginal participants are more likely to be dramatically impacted

65 Table A17 in the Appendix estimates a five-outcome MNL that incorporates the split (pro-liberalization/pro-protection) policy stances. This outcome is negatively correlated with firm size, but other results are substantively similar to those produced by Model 12. 
by policy reforms than the largest, most productive participants among whom these activities are highly concentrated. Finally, I have uncovered a group of firms for whom trade policy is not linked to a directional policy stance. Among these producers, those expecting no impact from reciprocal liberalization appear to be unrelated to firm size, while small firms are more likely than their larger counterparts to not know how they would be affected by reciprocal liberalization (Prediction 4).

\section{Conclusions and Implications}

Research on trade politics has largely focused on examining the sources of individual preferences ${ }^{66}$ over trade policy or conditions contributing to industry- or factor-based political cleavages. ${ }^{67}$ This paper contributes to an emerging body of work focusing on the role of firms in trade politics. While the influence of producers in trade politics has long been established, ${ }^{68}$ it is only more recently that these efforts have been put into a broader context, embedding politically active firms among those that do not involve themselves in trade politics.

Trade models with heterogeneous firms, based on extensions of the Melitz Model, can offer valuable insights to scholars interested in economic policies and their formation. By focusing on the variation in firm characteristics-in particular, productivity - that drive firm behaviors in economic markets, we can improve our understanding of the distributions of their policy stances and the nature of their participation in political markets as well. As a large body of trade research has found, high productivity firms are more likely than low productivity firms to engage foreign markets; this division of capabilities leads to heterogeneous effects from trade-policy reform. Producers that actively engage foreign markets or that could potentially do so are more likely to favor liberalization than smaller, less productive producers with prospects of serving only the domestic market.

Using a survey of Japanese manufacturers, I found evidence that this logic holds. Larger firms are more likely to favor liberalization, while smaller firms tend to prefer protection. These policy stances may be conditioned on ongoing internationalization methods; while only direct importing and indirect exporting show consistently significant influences on pro-trade stances, the lack of further significant results is likely

66 Scheve and Slaughter (2001); Mayda and Rodrik (2005); Hainmueller and Hiscox (2006); Roh and Tomz (2015).

67 Rogowski (1987); Hiscox (2002).

68 Bauer et al. (1972); Milner (1988); Grossman and Helpman (1994). 
the consequence of a lack of finer-grained data. In addition to this range of directional policy stances, a large portion of firms expect to remain unaffected by a change in trade policy; this group is not linked to size or productivity. Finally, a number of firms simply do not know how they would be impacted by trade liberalization. This category of respondents is most common among small firms that lack resources to research trade policy or its potential effects.

This is not to say that industry characteristics have been entirely subsumed by firm-oriented models. In several of the models, the comparative-advantage indicators are positively linked to pro-trade stances, indicating that characteristics intrinsic to these industries may be linked to trade-policy stances. While this paper contributes to our understanding of the distribution of trade-policy stances among firms, there is much room for further work, particularly in the study of how these stances compare to those across other issue areas, as well as what the distribution of these stances means for the policy-making process.

\section{Appendix}

\section{Survey Instrument}

For each of the following phenomena and/or policies, please select the respective influence of each on your firm. ${ }^{* *}$ Please answer strictly in terms of impact on your company/business interests, rather than providing your personal opinion. ${ }^{* *}$

The expansion and further liberalization of imports on manufacturing goods (including processed foods).

Deregulation and further liberalization of foreign markets.

Potential Responses:

1) Would bring positive effects.

2) Would not have much influence.

3) Would bring negative effects.

4) Would bring positive or negative effects, depending on the division or section.

5) Don't know. 


\section{Trade-Stance Index}

Trade Stance $=1$ (pro-trade) if Import (or Export) Liberalization would bring positive effects.

And Export (or Import) Liberalization would have positive/variable/no effects.

Trade Stance $=0$ (anti-trade) if Import (or Export) Liberalization would bring negative effects.

And Export (or Import) Liberalization would have negative/variable/no effects.

All Stances $=2$ if Trade Stance $=1 ; 1$ if Trade Stance $=0$; 0 if Neutral or Don't Know (in other words, neutral-neutral and any responses involving a DK) $=1$

Split pro/anti-trade stances are omitted (67 responses, distributed with no correlation to sales).

\section{Survey Representativeness}

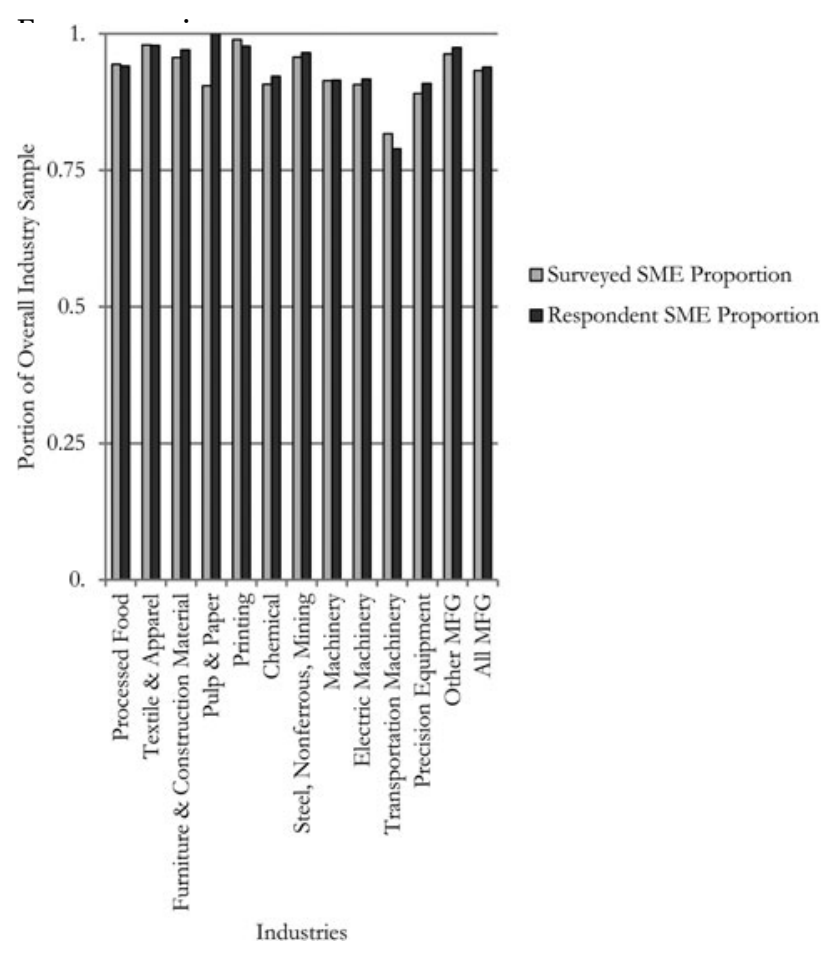

Figure A1: SMEs among Original Survey Sample and Respondent Sample 
Kimura and Kiyota 2006: 20.3 percent exporters, 12.8 percent FDI in 2000, not limited to MFG.

Kiyota and Urata 2008: 19.5 percent exporters, 19.1 percent importers, 12.5 percent direct two-way traders, 1994-2000 MFG panel.

Wakasugi and Tanaka 2012: 14.65 percent export to North America or Europe, 10.8 percent FDI to the same. 2005 MFG.

Tomiura et al. 2011: 20 percent offshore, 2006 MFG.

Table A1: Descriptive Statistics of Survey Respondents (Industry Means of Key Characteristics)

\begin{tabular}{lrrrrr}
\hline Industry & $\begin{array}{r}\text { Total } \\
\text { Firms }\end{array}$ & Sales $^{\mathbf{1}}$ & Employees & $\begin{array}{r}\text { Capital } \\
\text { Stock }^{\mathbf{2}}\end{array}$ & $\begin{array}{r}\text { Percent } \\
\text { SMEs }\end{array}$ \\
\hline Processed Food & 152 & 6,549 & 100.6 & 289.9 & $94.1 \%$ \\
Textile \& Apparel & 47 & 2,142 & 64.5 & 151.4 & $97.9 \%$ \\
Funiture \& Construction & 102 & 3,501 & 91.0 & 226.9 & $97.1 \%$ \\
$\quad$ Materials & & & & & \\
Paper \& Paper Products & 47 & 2,505 & 73.3 & 39.8 & $100 \%$ \\
Printing \& Publishing & 88 & 3,475 & 106.7 & 71.5 & $97.7 \%$ \\
Chemical & 180 & 14,866 & 180.4 & $1,964.8$ & $92.2 \%$ \\
Steel, Nonferrous \& & 230 & 5,243 & 108.8 & 181.1 & $96.5 \%$ \\
$\quad$ Mining & & & & & \\
Machinery & 235 & 7,770 & 182 & 547.1 & $91.5 \%$ \\
Electric Machinery & 181 & 10,204 & 199 & $1,246.0$ & $91.7 \%$ \\
Transportation Machinery & 38 & 11,794 & 286 & 407.9 & $79.0 \%$ \\
Precision Equipment & 33 & 7,779 & 193 & 1097.8 & $90.9 \%$ \\
Other MFG & 40 & 2,161 & 73 & 114.8 & $97.5 \%$ \\
& 1,373 & 7,441 & 144 & 646.9 & $93.9 \%$ \\
\hline
\end{tabular}

${ }^{1}$ In millions of yen, three-year average over 2008-2010.

${ }^{2}$ In millions of yen.

Table A2: Internationalization by Surveyed Japanese Manufacturers

\begin{tabular}{lrrrrrr}
\hline Industry & $\begin{array}{r}\text { Direct } \\
\text { Export }\end{array}$ & $\begin{array}{r}\text { Direct } \\
\text { Import }\end{array}$ & $\begin{array}{r}\text { Indirect } \\
\text { Export }\end{array}$ & $\begin{array}{r}\text { Indirect } \\
\text { Import }\end{array}$ & FDI & Outsource \\
\hline Processed Food & $7.2 \%$ & $12.5 \%$ & $22.4 \%$ & $64.5 \%$ & $10.5 \%$ & $19.1 \%$ \\
Textile \& Apparel & $17.0 \%$ & $42.6 \%$ & $14.9 \%$ & $53.2 \%$ & $17.0 \%$ & $48.9 \%$ \\
$\begin{array}{l}\text { Furniture \& } \\
\quad \text { Construction }\end{array}$ & $10.8 \%$ & $21.6 \%$ & $13.7 \%$ & $52.0 \%$ & $10.8 \%$ & $14.7 \%$ \\
$\quad$ Materials & & & & & & \\
\end{tabular}


(Table A2: Continued)

\begin{tabular}{|c|c|c|c|c|c|c|}
\hline Industry & $\begin{array}{l}\text { Direct } \\
\text { Export }\end{array}$ & $\begin{array}{l}\text { Direct } \\
\text { Import }\end{array}$ & $\begin{array}{r}\text { Indirect } \\
\text { Export }\end{array}$ & $\begin{array}{l}\text { Indirect } \\
\text { Import }\end{array}$ & FDI & Outsource \\
\hline $\begin{array}{l}\text { Paper \& Paper } \\
\text { Products }\end{array}$ & $8.5 \%$ & $14.9 \%$ & $14.9 \%$ & $61.7 \%$ & $8.5 \%$ & $14.9 \%$ \\
\hline $\begin{array}{l}\text { Printing \& } \\
\quad \text { Publishing }\end{array}$ & $4.6 \%$ & $10.2 \%$ & $8.0 \%$ & $33.0 \%$ & $2.3 \%$ & $14.8 \%$ \\
\hline Chemical & $20.0 \%$ & $25.6 \%$ & $28.3 \%$ & $49.4 \%$ & $21.1 \%$ & $24.4 \%$ \\
\hline $\begin{array}{l}\text { Steel, Nonferrous \& } \\
\quad \text { Mining }\end{array}$ & $11.3 \%$ & $18.3 \%$ & $14.4 \%$ & $29.6 \%$ & $11.7 \%$ & $18.3 \%$ \\
\hline Machinery & $32.8 \%$ & $32.3 \%$ & $36.2 \%$ & $37.5 \%$ & $15.4 \%$ & $25.5 \%$ \\
\hline Electric Machinery & $23.8 \%$ & $36.7 \%$ & $29.3 \%$ & $44.2 \%$ & $26.0 \%$ & $34.8 \%$ \\
\hline $\begin{array}{l}\text { Transportation } \\
\text { Machinery }\end{array}$ & $15.8 \%$ & $26.3 \%$ & $15.8 \%$ & $36.8 \%$ & $31.6 \%$ & $23.7 \%$ \\
\hline $\begin{array}{l}\text { Precision } \\
\text { Equipment }\end{array}$ & $24.2 \%$ & $45.5 \%$ & $57.6 \%$ & $45.5 \%$ & $15.2 \%$ & $27.3 \%$ \\
\hline Other MFG & $17.5 \%$ & $40.0 \%$ & $17.5 \%$ & $37.5 \%$ & $12.5 \%$ & $40.0 \%$ \\
\hline All Manufacturing & $17.6 \%$ & $25.4 \%$ & $23.5 \%$ & $43.9 \%$ & $15.4 \%$ & $24.0 \%$ \\
\hline $\begin{array}{l}\text { Comparative- } \\
\text { Advantage }\end{array}$ & $21.9 \%$ & $28.4 \%$ & $27.5 \%$ & $39.5 \%$ & $18.5 \%$ & $25.3 \%$ \\
\hline $\begin{array}{l}\text { Comparative- } \\
\text { Disadvantage }\end{array}$ & $9.5 \%$ & $19.5 \%$ & $16.0 \%$ & $52.3 \%$ & $9.7 \%$ & $21.6 \%$ \\
\hline
\end{tabular}

Table A3: Internationalization Premia, Bivariate OLS

\begin{tabular}{lrrrrr}
\hline Mode & $\begin{array}{r}\text { Log } \\
\text { Employment }\end{array}$ & $\begin{array}{r}\text { Log } \\
\text { Sales }\end{array}$ & Log K/L & $\begin{array}{r}\text { Log Capital } \\
\text { Stock }\end{array}$ & Log Y/L \\
\hline Direct Exporting & 0.73 & 0.91 & 0.09 & 0.82 & 0.18 \\
Direct Importing & 0.56 & 0.79 & 0.05 & 0.58 & 0.23 \\
Indirect Exporting & 0.61 & 0.81 & 0.13 & 0.72 & 0.18 \\
Indirect Importing & 0.31 & 0.42 & 0.02 & 0.30 & 0.14 \\
Two-way Trade & 0.64 & 0.80 & 0.07 & 0.71 & 0.18 \\
$\quad$ Direct Two-Way & 0.71 & 0.96 & 0.11 & 0.82 & 0.26 \\
$\quad$ Trade & 0.40 & 0.64 & -0.11 & 0.29 & 0.24 \\
Offshore & & & & & \\
$\quad$ Outsourcing & 1.30 & 1.57 & 0.16 & 1.39 & 0.27 \\
FDI & & & & & \\
\hline
\end{tabular}


Table A4: Internationalization Premia, Bivariate OLS with Industry Fixed Effects

\begin{tabular}{lrrrrr}
\hline Mode & Log Employment & Log Sales & Log K/L & Log Capital Stock & Log Y/L \\
\hline Direct Exporting & 0.73 & 0.98 & 0.19 & 0.93 & 0.25 \\
Direct Importing & 0.58 & 0.85 & 0.15 & 0.71 & 0.28 \\
Indirect Exporting & 0.62 & 0.85 & 0.22 & 0.83 & 0.22 \\
Indirect Importing & 0.35 & 0.42 & -0.00 & 0.32 & 0.11 \\
Two-way Trade & 0.65 & 0.84 & 0.17 & 0.82 & 0.22 \\
Direct Two-Way Trade & 0.71 & 1.02 & 0.24 & 0.94 & 0.32 \\
Offshore Outsourcing & 0.43 & 0.70 & -0.02 & 0.41 & 0.27 \\
FDI & 1.29 & 1.57 & 0.22 & 1.46 & 0.28 \\
\hline
\end{tabular}

Table A5: Internationalization Mode Correlations

\begin{tabular}{lrrrrrrr}
\hline & Sales & D Export & D Import & FDI & Offshore & I Export & I Import \\
\hline Sales & 1.000 & & & & & & \\
D Export & 0.230 & 1.000 & & & & & \\
D Import & 0.227 & 0.405 & 1.000 & & & & \\
FDI & 0.378 & 0.269 & 0.367 & 1.000 & & & \\
Offshore & 0.166 & 0.144 & 0.405 & 0.222 & 1.000 & & \\
I Export & 0.224 & 0.268 & 0.230 & 0.195 & 0.150 & 1.000 & \\
I Import & 0.150 & 0.062 & -0.077 & 0.065 & 0.117 & 0.115 & 1.000 \\
\hline
\end{tabular}

\section{Robustness Tests}

Table A6: Internationalization Activities and Trade Stances

\begin{tabular}{lrrrrr}
\hline & Model A1 & Model A2 & Model A3 & Model A4 & Model A5 \\
\hline Firm Size & $0.042^{\star \star \star}$ & $0.034^{\star \star \star}$ & $0.040^{\star \star \star}$ & $0.033^{\star \star \star}$ & $0.025^{\star \star}$ \\
& $(0.009)$ & $(0.010)$ & $(0.009)$ & $(0.009)$ & $(0.011)$ \\
RCA & $0.041^{\star \star \star}$ & $0.037^{\star \star \star}$ & $0.039^{\star \star \star}$ & $0.039^{\star \star \star}$ & $0.033^{\star \star \star}$ \\
& $(0.008)$ & $(0.008)$ & $(0.08)$ & $(0.007)$ & $(0.008)$ \\
Direct Exporter & 0.045 & 0.036 & 0.047 & 0.015 & 0.010 \\
& $(0.058)$ & $(0.056)$ & $(0.060)$ & $(0.063)$ & $(0.062)$ \\
Direct Importer & $0.201^{\star \star \star}$ & $0.180^{\star \star \star}$ & $0.184^{\star \star \star}$ & $0.191^{\star \star \star}$ & $0.160^{\star \star}$ \\
& $(0.039)$ & $(0.054)$ & $(0.056)$ & $(0.039)$ & $(0.072)$ \\
FDI & & 0.095 & & & 0.090 \\
& & $(0.077)$ & & & $(0.074)$ \\
Offshoring & & & 0.051 & & 0.026 \\
& & & $(0.052)$ & & $(0.054)$
\end{tabular}


(Table A6: Continued)

\begin{tabular}{lrrrrr}
\hline & Model A1 & Model A2 & Model A3 & Model A4 & Model A5 \\
\hline Indirect Exporter & & & & $0.134^{\star \star \star}$ & $0.130^{\star \star \star}$ \\
& & & & $(0.029)$ & $(0.029)$ \\
Indirect Importer & & & 0.034 & 0.030 \\
& & & & $(0.034)$ & $(0.035)$ \\
Constant & $-1.581^{\star \star \star}$ & $-1.376^{\star \star \star}$ & $-1.563^{\star \star \star}$ & $-1.498^{\star \star \star}$ & $-1.299^{\star \star \star}$ \\
& $(0.397)$ & $(0.350)$ & $(0.301)$ & $(0.288)$ & $(0.337)$ \\
Observations & 684 & 684 & 684 & 684 & 684 \\
Pseudo- $R^{2}$ & 0.062 & 0.065 & 0.063 & 0.074 & 0.077 \\
Wald Chi2 & 116.52 & 371.52 & 691.05 & 155.71 & 1332.5 \\
AIC & 897.95 & 896.89 & 898.65 & 890.72 & 891.46 \\
\hline
\end{tabular}

*** $\mathrm{p}<0.01 * \star \mathrm{p}<0.05 * \mathrm{p}<0.1$

All logit regressions run with heteroskedastically robust standard errors clustered at the industry level, with average marginal effects reported.

Table A7: Trade Stances and Internationalization, using Skilled Labor as Comparative-Advantage Proxy

\begin{tabular}{|c|c|c|c|c|c|}
\hline & Model A6 & Model A7 & Model A8 & Model A9 & Model A10 \\
\hline Firm Size & $\begin{array}{r}0.043^{\star \star \star} \\
(0.009)\end{array}$ & $\begin{array}{r}0.035^{\star \star *} \\
(0.010)\end{array}$ & $\begin{array}{r}0.041^{\star \star \star} \\
(0.009)\end{array}$ & $\begin{array}{r}0.034^{\star \star \star} \\
(0.010)\end{array}$ & $\begin{array}{r}0.025^{\star \star} \\
(0.011)\end{array}$ \\
\hline Skilled Labor & $\begin{array}{r}0.037^{\star \star \star} \\
(0.008)\end{array}$ & $\begin{array}{r}0.033^{\star \star \star} \\
(0.007)\end{array}$ & $\begin{array}{r}0.035^{\star \star \star} \\
(0.07)\end{array}$ & $\begin{array}{r}0.030^{\star \star \star} \\
(0.010)\end{array}$ & $\begin{array}{r}0.025^{\star \star \star} \\
(0.009)\end{array}$ \\
\hline Direct Exporter & $\begin{array}{r}0.044 \\
(0.058)\end{array}$ & $\begin{array}{r}0.035 \\
(0.056)\end{array}$ & $\begin{array}{r}0.046 \\
(0.060)\end{array}$ & $\begin{array}{r}0.018 \\
(0.063)\end{array}$ & $\begin{array}{r}0.012 \\
(0.062)\end{array}$ \\
\hline Direct Importer & $\begin{array}{r}0.199 * \star \star \\
(0.041)\end{array}$ & $\begin{array}{r}0.177^{\star \star \star} \\
(0.055)\end{array}$ & $\begin{array}{r}0.180^{\star \star \star} \\
(0.058)\end{array}$ & $\begin{array}{r}0.189^{\star \star \star} \\
(0.041)\end{array}$ & $\begin{array}{r}0.156^{\star \star} \\
(0.074)\end{array}$ \\
\hline FDI & & $\begin{array}{r}0.098 \\
(0.077)\end{array}$ & & & $\begin{array}{r}0.094 \\
(0.074)\end{array}$ \\
\hline Offshoring & & & $\begin{array}{r}0.053 \\
(0.052)\end{array}$ & & $\begin{array}{r}0.030 \\
(0.054)\end{array}$ \\
\hline Indirect Exporter & & & & $\begin{array}{r}0.132^{\star \star \star} \\
(0.030)\end{array}$ & $\begin{array}{r}0.129^{\star \star \star} \\
(0.030)\end{array}$ \\
\hline Indirect Importer & & & & $\begin{array}{r}0.029 \\
(0.033)\end{array}$ & $\begin{array}{r}0.026 \\
(0.034)\end{array}$ \\
\hline Constant & $\begin{array}{r}-1.598^{\star \star \star} \\
(0.304)\end{array}$ & $\begin{array}{r}-1.386^{\star \star \star} \\
(0.360)\end{array}$ & $\begin{array}{r}-1.580^{\star \star \star} \\
(0.307)\end{array}$ & $\begin{array}{r}-1.510^{\star \star \star} \\
(0.293)\end{array}$ & $\begin{array}{r}-1.301^{\star \star \star} \\
(0.345)\end{array}$ \\
\hline Observations & 684 & 684 & 684 & 684 & 684 \\
\hline
\end{tabular}


(Table A7: Continued)

\begin{tabular}{lrrrrr}
\hline & Model A6 & Model A7 & Model A8 & Model A9 & Model A10 \\
\hline Pseudo-R & 0.061 & 0.064 & 0.062 & 0.072 & 0.076 \\
Wald Chi2 & 155.38 & 425.89 & 553.87 & 95.27 & 356.97 \\
\hline
\end{tabular}

*** $\mathrm{p}<0.01{ }^{\star *} \mathrm{p}<0.05{ }^{*} \mathrm{p}<0.1$

All logit regressions run with heteroskedastically robust standard errors clustered at the industry level, with average marginal effects reported. Results using the trade-balance dummy are comparable.

Table A8: Trade Stances and Internationalization, Conditional Logits

\begin{tabular}{lrrrr}
\hline & Model A11 & Model A12 & Model A13 & Model A14 \\
\hline Firm Size & $0.175^{\star \star \star}$ & $0.143^{\star \star}$ & $0.166^{\star \star \star}$ & $0.135^{\star \star}$ \\
& $(0.059)$ & $(0.062)$ & $(0.059)$ & $(0.061)$ \\
Direct Exporter & 0.179 & 0.144 & 0.192 & 0.071 \\
& $(0.222)$ & $(0.224)$ & $(0.222)$ & $(0.227)$ \\
Direct Importer & $0.842^{\star \star \star}$ & $0.759^{\star \star \star}$ & $0.772^{\star \star \star}$ & $0.818^{\star \star \star}$ \\
& $(0.196)$ & $(0.202)$ & $(0.206)$ & $(0.202)$ \\
FDI & & $0.395^{\star}$ & & \\
& & $(0.237)$ & & \\
Offshoring & & & 0.217 & \\
& & & $(0.195)$ & \\
Indirect Exporter & & & & $0.594^{\star \star \star}$ \\
& & & & $(0.190)$ \\
Indirect Importer & 684 & 684 & 684 & 0.124 \\
& & & & $0.172)$ \\
Observations & 45.41 & 48.21 & 46.64 & 684 \\
Wald Chi2 & & &
\end{tabular}

*** $\mathrm{p}<0.01{ }^{\star *} \mathrm{p}<0.05{ }^{*} \mathrm{p}<0.1$

Fixed-effect logits have regression coefficients reported; the effects here are comparable in scope to those reported in other tables. Random-effects logits produce comparable results. 
Table A9: Trade Stances and Market Access

\begin{tabular}{|c|c|c|c|c|c|}
\hline & Model A15 & Model A16 & Model A17 & Model A18 & Model A19 \\
\hline \multirow[t]{2}{*}{ Firm Size } & $0.042^{\star \star \star}$ & $0.041^{\star \star \star}$ & $0.032^{\star \star \star}$ & $0.032^{\star \star \star}$ & $0.032^{\star \star \star}$ \\
\hline & (0.008) & (0.009) & (0.009) & (0.010) & $(0.010)$ \\
\hline \multirow[t]{2}{*}{ RCA } & $0.039 * * \star$ & $0.054^{\star \star \star}$ & $0.036^{\star \star \star}$ & $0.049^{\star * *}$ & $0.046^{\star \star *}$ \\
\hline & (0.008) & (0.010) & $(0.08)$ & (0.010) & $(0.010)$ \\
\hline \multirow[t]{2}{*}{ Direct Exporter } & 0.044 & 0.046 & 0.015 & 0.017 & 0.016 \\
\hline & (0.059) & $(0.058)$ & $(0.064)$ & $(0.063)$ & $(0.063)$ \\
\hline \multirow[t]{2}{*}{ Direct Importer } & $0.202^{\star \star \star}$ & 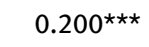 & $0.191^{\star \star \star}$ & $0.189^{\star \star \star}$ & $0.190^{\star \star \star}$ \\
\hline & (0.039) & $(0.040)$ & $(0.036)$ & $(0.040)$ & $(0.039)$ \\
\hline \multirow[t]{2}{*}{ Indirect Exporter } & & & $0.133^{\star \star \star}$ & $0.133^{\star \star \star}$ & $0.133^{\star \star \star}$ \\
\hline & & & $(0.028)$ & $(0.028)$ & $(0.028)$ \\
\hline \multirow[t]{2}{*}{ Indirect Importer } & & & 0.035 & 0.031 & 0.032 \\
\hline & & & $(0.034)$ & $(0.034)$ & $(0.034)$ \\
\hline \multirow[t]{2}{*}{ Industry Imports } & 0.004 & & 0.006 & & 0.004 \\
\hline & $(0.008)$ & & $(0.005)$ & & $(0.003)$ \\
\hline \multirow[t]{2}{*}{ AWT } & & $0.009^{\star \star \star}$ & & $0.007^{\star \star}$ & $0.007^{\star}$ \\
\hline & & $(0.003)$ & & (0.003) & $(0.003)$ \\
\hline \multirow[t]{2}{*}{ Constant } & $-1.914^{\star \star \star}$ & 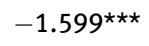 & $-1.950^{\star \star \star}$ & $-1.498^{\star \star \star}$ & $-1.852^{\star \star \star}$ \\
\hline & (0.673) & (0.298) & $(0.442)$ & (0.288) & $(0.300)$ \\
\hline Observations & 684 & 684 & 684 & 684 & 684 \\
\hline Pseudo- $\mathrm{R}^{2}$ & 0.062 & 0.062 & 0.074 & 0.074 & 0.074 \\
\hline Wald Chi2 & 123.95 & 297.83 & 169.42 & 281.32 & 381.20 \\
\hline $\mathrm{AIC}$ & 899.87 & 899.33 & 892.57 & 892.32 & 894.24 \\
\hline
\end{tabular}

*** $\mathrm{p}<0.01{ }^{* \star} \mathrm{p}<0.05 * \mathrm{p}<0.1$

All logit regressions run with heteroskedastically robust standard errors clustered at the industry level, with average marginal effects reported. 
Table A10: Market Access, Skilled Labor

\begin{tabular}{|c|c|c|c|c|c|c|}
\hline & Model A20 & Model A21 & Model A22 & Model A23 & Model A24 & Model A25 \\
\hline Firm Size & $\begin{array}{r}0.042^{\star \star \star} \\
(0.008)\end{array}$ & $\begin{array}{r}0.043^{* \star *} \\
(0.009)\end{array}$ & $\begin{array}{r}0.042^{\star \star \star} \\
(0.009)\end{array}$ & $\begin{array}{r}0.042^{\star \star \star} \\
(0.008)\end{array}$ & $\begin{array}{c}0.041^{\star \star} \\
(0.008)\end{array}$ & $\begin{array}{r}0.041^{\star \star \star} \\
(0.008)\end{array}$ \\
\hline Skilled Labor & $\begin{array}{r}0.036 * \star \star \\
(0.007)\end{array}$ & $\begin{array}{r}0.041 * \star \star \\
(0.010)\end{array}$ & $\begin{array}{r}0.047^{\star * \star} \\
(0.011)\end{array}$ & & & \\
\hline Trade Balance & & & & $\begin{array}{r}0.079 \star \star \star \\
(0.026)\end{array}$ & $\begin{array}{r}0.085^{\star \star \star} \\
(0.028)\end{array}$ & $\begin{array}{r}0.114^{\star \star} \\
(0.044)\end{array}$ \\
\hline Direct Exporter & $\begin{array}{r}0.041 \\
(0.059)\end{array}$ & $\begin{array}{r}0.044 \\
(0.058)\end{array}$ & $\begin{array}{r}0.044 \\
(0.058)\end{array}$ & $\begin{array}{r}0.044 \\
(0.061)\end{array}$ & $\begin{array}{r}0.045 \\
(0.061)\end{array}$ & $\begin{array}{r}0.045 \\
(0.060)\end{array}$ \\
\hline Direct Importer & $\begin{array}{r}0.199 \star \star \star \\
(0.041)\end{array}$ & $\begin{array}{r}0.198 * \star \star \\
(0.055)\end{array}$ & $\begin{array}{r}0.199 * \star \star \\
(0.041)\end{array}$ & $\begin{array}{r}0.206^{\star \star \star} \\
(0.038)\end{array}$ & $\begin{array}{r}0.207^{\star \star \star} \\
(0.037)\end{array}$ & $\begin{array}{r}0.207^{\star \star \star} \\
(0.038)\end{array}$ \\
\hline Industry Imports & $\begin{array}{c}0.013^{\star \star} \\
(0.006)\end{array}$ & & $\begin{array}{r}1.06 \times 10^{-10} \\
\left(6.73 \times 10^{-11}\right)\end{array}$ & $\begin{array}{l}-0.004 \\
(0.013)\end{array}$ & & $\begin{array}{r}-0.011 \\
(0.014)\end{array}$ \\
\hline AWT & & $\begin{array}{r}0.004 \\
(0.003)\end{array}$ & $\begin{array}{r}0.006 \\
(0.004)\end{array}$ & & $\begin{array}{r}0.004 \\
(0.004)\end{array}$ & $\begin{array}{r}0.008 \\
(0.006)\end{array}$ \\
\hline Constant & $\begin{array}{r}-2.547^{\star \star \star} \\
(0.570)\end{array}$ & $\begin{array}{r}-1.608^{\star \star \star} \\
(0.308)\end{array}$ & $\begin{array}{r}-1.655^{\star \star \star} \\
(0.305)\end{array}$ & $\begin{array}{l}-1.478 \\
(1.020)\end{array}$ & $\begin{array}{r}-1.805^{\star \star \star} \\
(0.269)\end{array}$ & $\begin{array}{l}-1.068 \\
(1.052)\end{array}$ \\
\hline Observations & 684 & 684 & 684 & 684 & 684 & 684 \\
\hline Pseudo- $R^{2}$ & 0.062 & 0.064 & 0.061 & 0.060 & 0.060 & 0.060 \\
\hline Wald Chi2 & 274.54 & 211.09 & 50.60 & 151.78 & 131.79 & 200.57 \\
\hline
\end{tabular}

*** $\mathrm{p}<0.01{ }^{\star *} \mathrm{p}<0.05{ }^{*} \mathrm{p}<0.1$

All logit regressions run with heteroskedastically robust standard errors clustered at the industry level, with average marginal effects reported. 
Table A11: Multinomial Trade Stances, Skilled Labor

\begin{tabular}{|c|c|c|c|c|}
\hline & \multicolumn{2}{|r|}{ Model A26 } & \multicolumn{2}{|r|}{ Model A27 } \\
\hline & Anti-Trade & Pro-Trade & Anti-Trade & Pro-Trade \\
\hline \multirow[t]{2}{*}{ Firm Size } & -0.010 & $0.033^{\star \star \star}$ & -0.009 & $0.033^{\star \star \star}$ \\
\hline & $(0.009)$ & $(0.005)$ & $(0.008)$ & $(0.005)$ \\
\hline \multirow[t]{2}{*}{ Skilled Labor } & -0.009 & $0.026^{\star \star}$ & -0.024 & $0.042^{\star \star \star}$ \\
\hline & $(0.017)$ & $(0.010)$ & $(0.026)$ & $(0.015)$ \\
\hline \multirow[t]{2}{*}{ Direct Exporter } & $-0.080^{\star \star \star}$ & 0.079 & $-0.080^{\star \star \star}$ & $0.080^{\star}$ \\
\hline & $(0.029)$ & $(0.045)$ & $(0.029)$ & $(0.045)$ \\
\hline \multirow[t]{2}{*}{ Direct Importer } & $-0.059^{\star}$ & $0.162^{\star \star \star}$ & $-0.058^{\star}$ & $0.161^{\star \star \star}$ \\
\hline & $(0.032)$ & (0.039) & (0.035) & (0.039) \\
\hline \multirow[t]{2}{*}{ AWT } & & & -0.014 & $0.015^{\star \star}$ \\
\hline & & & $(0.010)$ & $(0.006)$ \\
\hline \multirow[t]{2}{*}{ Constant } & -0.330 & $-1.865^{\star \star \star}$ & -0.303 & $-1.923^{\star \star *}$ \\
\hline & $(0.345)$ & $(0.296)$ & $(0.353)$ & $(0.302)$ \\
\hline Observations & \multicolumn{2}{|c|}{1,173} & \multicolumn{2}{|c|}{1,173} \\
\hline Pseudo- $R^{2}$ & \multicolumn{2}{|c|}{0.033} & \multicolumn{2}{|c|}{0.035} \\
\hline Wald Chi2 & \multicolumn{2}{|c|}{$1,647.96$} & \multicolumn{2}{|c|}{82.26} \\
\hline
\end{tabular}

*** $p<0.01{ }^{\star *} p<0.05{ }^{*} p<0.1$

All multinomial logit regressions run with heteroskedastically robust standard errors clustered at the industry level, with average marginal effects reported.

Table A12: Multinomial Trade Stances, Trade Balance

\begin{tabular}{|c|c|c|c|c|}
\hline & \multicolumn{2}{|r|}{ Model A28 } & \multicolumn{2}{|r|}{ Model A29 } \\
\hline & Anti-Trade & Pro-Trade & Anti-Trade & Pro-Trade \\
\hline Firm Size & $\begin{array}{r}-0.009 \\
(0.010)\end{array}$ & $\begin{array}{r}0.032^{\star \star \star} \\
(0.006)\end{array}$ & $\begin{array}{l}-0.007 \\
(0.009)\end{array}$ & $\begin{array}{r}0.030^{\star \star \star} \\
(0.006)\end{array}$ \\
\hline Trade Balance & $\begin{array}{r}-0.064 \\
(0.049)\end{array}$ & $\begin{array}{c}0.067^{\star \star} \\
(0.033)\end{array}$ & $\begin{array}{r}-0.117^{\star \star} \\
(0.047)\end{array}$ & $\begin{array}{r}0.115^{\star \star \star} \\
(0.032)\end{array}$ \\
\hline Direct Exporter & $\begin{array}{r}-0.072^{\star \star \star} \\
(0.027)\end{array}$ & $\begin{array}{c}0.077^{\star} \\
(0.046)\end{array}$ & $\begin{array}{r}-0.072^{\star \star \star} \\
(0.027)\end{array}$ & $\begin{array}{c}0.077^{\star} \\
(0.046)\end{array}$ \\
\hline Direct Importer & $\begin{array}{r}-0.059^{\star} \\
(0.031)\end{array}$ & $\begin{array}{r}0.167^{\star \star \star} \\
(0.037)\end{array}$ & $\begin{array}{r}-0.062^{\star} \\
(0.032)\end{array}$ & $\begin{array}{r}0.170^{\star \star *} \\
(0.036)\end{array}$ \\
\hline AWT & & & $\begin{array}{r}-0.022 \\
(0.008)\end{array}$ & $\begin{array}{r}0.019^{\star \star \star} \\
(0.006)\end{array}$ \\
\hline Constant & $\begin{array}{r}-0.227 \\
(0.347)\end{array}$ & $\begin{array}{r}-1.991^{\star \star \star} \\
(0.318)\end{array}$ & $\begin{array}{l}-0.099 \\
(0.396)\end{array}$ & $\begin{array}{r}-2.162^{\star \star \star} \\
(0.300)\end{array}$ \\
\hline Observations & \multicolumn{2}{|c|}{1,173} & \multicolumn{2}{|c|}{1,173} \\
\hline Pseudo- $\mathrm{R}^{2}$ & \multicolumn{2}{|c|}{0.034} & \multicolumn{2}{|c|}{0.038} \\
\hline Wald Chi2 & \multicolumn{2}{|c|}{129.33} & \multicolumn{2}{|c|}{89.22} \\
\hline
\end{tabular}

$\star \star \star ~ p<0.01{ }^{* \star} \mathrm{p}<0.05{ }^{*} \mathrm{p}<0.1$

All multinomial logit regressions run with heteroskedastically robust standard errors clustered at the industry level, with average marginal effects reported. 
Table A13: Trade Stances with Multiple Outcomes

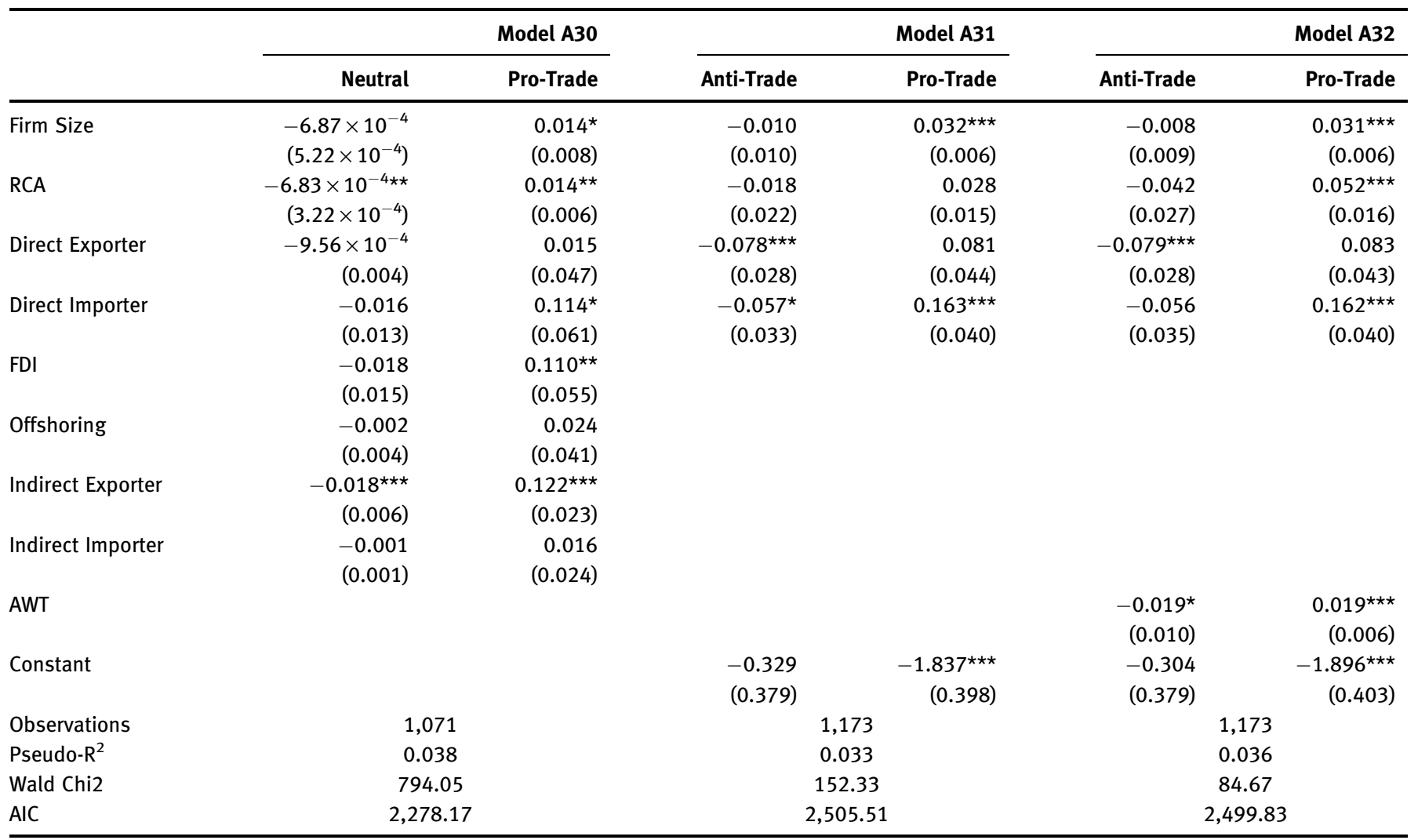

$\star \star \star ~ p<0.01 * \star p<0.05 * \mathrm{p}<0.1$

All multinomial logit regressions run with heteroskedastically robust standard errors clustered at the industry level, with average marginal effects reported. 
Table A14: Multinomial Trade Stances, Four-Outcome Models, RCA

\begin{tabular}{|c|c|c|c|c|c|c|}
\hline & \multicolumn{3}{|r|}{ Model A33 } & \multicolumn{3}{|r|}{ Model A34 } \\
\hline & Anti-Trade & Pro-Trade & Don't Know & Anti-Trade & Pro-Trade & Don’t Know \\
\hline \multirow[t]{2}{*}{ Firm Size } & -0.010 & $0.033^{\star \star \star}$ & $-0.010^{\star \star \star}$ & -0.008 & $0.032^{\star \star \star}$ & $-0.009^{\star \star \star}$ \\
\hline & $(0.010)$ & $(0.006)$ & $(0.003)$ & $(0.008)$ & $(0.006)$ & (0.003) \\
\hline \multirow[t]{2}{*}{ RCA } & -0.018 & $0.028^{\star}$ & 0.006 & -0.042 & $0.053^{\star \star \star}$ & -0.004 \\
\hline & $(0.022)$ & $(0.015)$ & $(0.008)$ & $(0.027)$ & $(0.015)$ & $(0.010)$ \\
\hline \multirow[t]{2}{*}{ Direct Exporter } & $-0.079^{\star \star \star}$ & $0.080^{*}$ & $-0.030^{*}$ & $-0.080^{\star \star \star}$ & $0.082^{*}$ & $-0.031^{*}$ \\
\hline & $(0.028)$ & $(0.044)$ & $(0.018)$ & $(0.028)$ & $(0.042)$ & $(0.017)$ \\
\hline \multirow[t]{2}{*}{ Direct Importer } & $-0.057^{\star}$ & $0.163^{\star \star \star}$ & -0.014 & -0.057 & $0.162^{\star \star \star}$ & -0.013 \\
\hline & $(0.033)$ & $(0.040)$ & $(0.011)$ & $(0.035)$ & $(0.040)$ & $(0.011)$ \\
\hline \multirow[t]{2}{*}{ AWT } & & & & $-0.018^{\star}$ & $0.019^{\star \star \star}$ & $-0.009^{\star \star}$ \\
\hline & & & & $(0.010)$ & $(0.006)$ & $(0.005)$ \\
\hline \multirow[t]{2}{*}{ Constant } & 0.058 & $-1.452^{\star \star \star}$ & $-0.681^{*}$ & 0.098 & $-1.496^{\star \star \star}$ & $-0.616^{\star}$ \\
\hline & $(0.381)$ & $(0.315)$ & $(0.364)$ & $(0.377)$ & $(0.315)$ & $(0.360)$ \\
\hline Observations & & 1,173 & & & 1,173 & \\
\hline Pseudo- $R^{2}$ & & 0.029 & & & 0.033 & \\
\hline
\end{tabular}

$\star \star \star ~ p<0.01 * \star p<0.05 * p<0.1$

All multinomial logit regressions run with heteroskedastically robust standard errors clustered at the industry level, with average marginal effects reported. 
Table A15: Multinomial Trade Stances, Four-Outcome Models, Skilled Labor

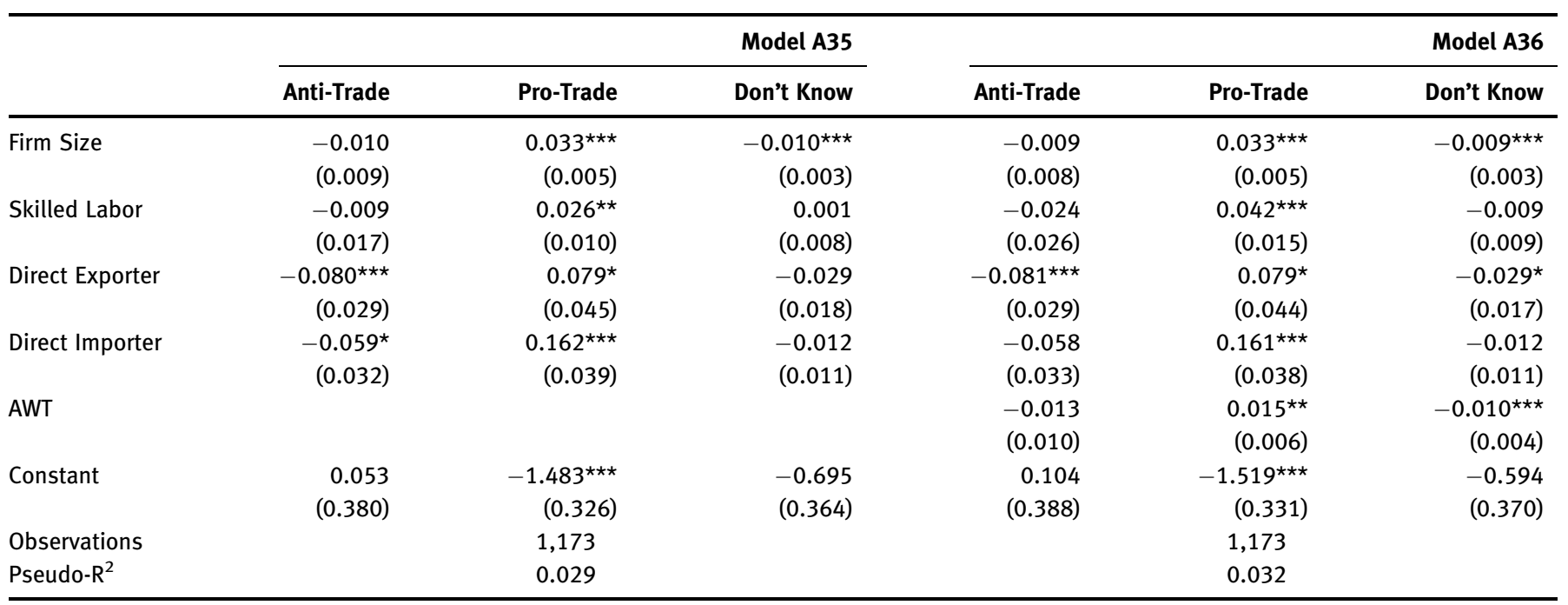

$\star \star \star ~ p<0.01 * * \mathrm{p}<0.05 * \mathrm{p}<0.1$

All multinomial logit regressions run with heteroskedastically robust standard errors clustered at the industry level, with average marginal effects reported. 
Table A16: Multinomial Trade Stances, Four-Outcome Models, Trade Balance

\begin{tabular}{|c|c|c|c|c|c|c|}
\hline & \multicolumn{3}{|r|}{ Model A37 } & \multicolumn{3}{|r|}{ Model A38 } \\
\hline & Anti-Trade & Pro-Trade & Don’t Know & Anti-Trade & Pro-Trade & Don’t Know \\
\hline \multirow[t]{2}{*}{ Firm Size } & -0.009 & $0.032^{\star \star \star}$ & $-0.010^{\star \star \star}$ & -0.007 & 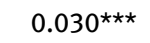 & $-0.009 * * \star$ \\
\hline & $(0.010)$ & $(0.006)$ & $(0.003)$ & $(0.009)$ & $(0.006)$ & (0.003) \\
\hline \multirow[t]{2}{*}{ Trade Balance } & -0.063 & $0.067^{\star \star}$ & 0.008 & $-0.117^{\star \star}$ & $0.115^{\star \star \star}$ & -0.012 \\
\hline & $(0.049)$ & $(0.033)$ & $(0.021)$ & $(0.047)$ & $(0.031)$ & $(0.023)$ \\
\hline \multirow[t]{2}{*}{ Direct Exporter } & $-0.073^{\star \star \star}$ & $0.077^{\star}$ & $-0.030^{*}$ & $-0.073^{\star \star \star}$ & $0.077^{\star}$ & $-0.030^{\star}$ \\
\hline & $(0.027)$ & $(0.046)$ & $(0.018)$ & $(0.027)$ & $(0.045)$ & $(0.018)$ \\
\hline \multirow[t]{2}{*}{ Direct Importer } & $-0.059^{\star}$ & $0.167^{\star \star \star}$ & -0.013 & $-0.062^{\star}$ & $0.170^{\star \star \star}$ & -0.014 \\
\hline & $(0.031)$ & $(0.036)$ & $(0.011)$ & $(0.033)$ & $(0.036)$ & $(0.010)$ \\
\hline \multirow[t]{2}{*}{ AWT } & & & & -0.021 & $0.020^{\star \star \star}$ & $-0.010^{\star \star}$ \\
\hline & & & & $(0.008)$ & $(0.006)$ & $(0.004)$ \\
\hline \multirow[t]{2}{*}{ Constant } & 0.139 & $-1.627^{\star \star \star}$ & $-0.765^{\star}$ & 0.340 & $-1.727^{\star \star \star}$ & -0.485 \\
\hline & $(0.377)$ & $(0.322)$ & $(0.392)$ & $(0.455)$ & $(0.303)$ & $(0.478)$ \\
\hline Observations & & 1,173 & & & 1,173 & \\
\hline Pseudo- $R^{2}$ & & 0.030 & & & 0.035 & \\
\hline
\end{tabular}

$* \star * \mathrm{p}<0.01{ }^{* *} \mathrm{p}<0.05{ }^{*} \mathrm{p}<0.1$

All multinomial logit regressions run with heteroskedastically robust standard errors clustered at the industry level, with average marginal effects reported. 
Table A17: Multinomial Trade Stances, Five-Outcome Model

\begin{tabular}{|c|c|c|c|c|c|}
\hline & \multicolumn{5}{|r|}{ Model A39 } \\
\hline & Don’t Know & Anti-Trade & Neutral & Split & Pro-Trade \\
\hline \multirow[t]{2}{*}{ Firm Size } & $-0.008^{\star \star}$ & -0.004 & 0.008 & $-0.008^{\star \star}$ & $0.012^{\star}$ \\
\hline & $(0.004)$ & $(0.012)$ & $(0.010)$ & $(0.004)$ & $(0.007)$ \\
\hline \multirow[t]{2}{*}{ RCA } & 0.006 & -0.020 & -0.012 & $0.010^{\star \star}$ & 0.016 \\
\hline & $(0.007)$ & $(0.012)$ & $(0.022)$ & $(0.004)$ & $(0.012)$ \\
\hline \multirow[t]{2}{*}{ Direct Exporter } & -0.025 & 0.014 & -0.045 & 0.007 & 0.050 \\
\hline & $(0.017)$ & $(0.038)$ & $(0.032)$ & $(0.025)$ & $(0.052)$ \\
\hline \multirow[t]{2}{*}{ Direct Importer } & -0.009 & $-0.093^{\star \star \star}$ & $-4.15 \times 10-4$ & 0.010 & $0.093^{*}$ \\
\hline & $(0.014)$ & $(0.028)$ & $(0.036)$ & $(0.029)$ & $(0.056)$ \\
\hline \multirow[t]{2}{*}{ FDI } & 0.036 & -0.037 & $-0.132^{\star \star \star}$ & 0.030 & $0.103^{\star \star *}$ \\
\hline & $(0.036)$ & $(0.036)$ & $(0.036)$ & $(0.034)$ & $(0.046)$ \\
\hline \multirow[t]{2}{*}{ Offshoring } & -0.018 & 0.016 & $-0.047^{\star \star}$ & -0.007 & 0.055 \\
\hline & $(0.014)$ & $(0.045)$ & $(0.022)$ & $(0.010)$ & $(0.038)$ \\
\hline \multirow[t]{2}{*}{ Indirect Exporter } & $-0.047^{\star \star \star}$ & -0.036 & $-0.119^{\star \star \star}$ & 0.025 & $0.176^{\star \star \star}$ \\
\hline & $(0.016)$ & $(0.026)$ & $(0.022)$ & $(0.023)$ & (0.017) \\
\hline \multirow[t]{2}{*}{ Indirect Importer } & -0.014 & 0.029 & $-0.056^{\star}$ & -0.008 & $0.049^{\star \star}$ \\
\hline & $(0.014)$ & $(0.031)$ & (0.033) & $(0.008)$ & $(0.020)$ \\
\hline Observations & \multicolumn{5}{|c|}{1,173} \\
\hline Pseudo- $R^{2}$ & \multicolumn{5}{|c|}{0.052} \\
\hline AIC & \multicolumn{5}{|c|}{$3,219.35$} \\
\hline
\end{tabular}

\section{References}

Abel-Koch, Jennifer. 2013a. "Endogenous Trade Policy with Heterogeneous Firms.” Manuscript.

Abel-Koch, Jennifer. 2013b. "Who Uses Intermediaries in International Trade? Evidence from Firmlevel Survey Data.” The World Economy 36 (8): 1041-1064.

Alt, James E., Frederik Carlsen, Per Heum, and Kare Johansen. 1999. "Asset Specificity and the Political Behavior of Firms: Lobbying for Subsidies in Norway." International Organization 53 (1): 99-116.

Alt, James and Michael Gilligan. 1994. "The Political Economy of Trading States: Factor Specificity, Collective Action Problems and Domestic Political Institutions." Journal of Political Philosophy 2 (2): 165-192.

Alvarez, Roberto and Ricardo A. Lopez. 2005. "Exporting and Performance: Evidence from Chilean Plants." Canadian Journal of Economics 38 (4): 1384-1400.

Bauer, Raymond Augustine, Ithiel de Sola Pool, and Lewis Anthony Dexter. 1972. American Business and Public Policy: The Politics of Foreign Trade, Second Edition. Chicago: AldineAtherton, Inc.

Bernard, Andrew B., Jonathan Eaton, J. Bradford Jensen, and Samuel S. Kortum. 2003. "Plants and Productivity in International Trade.” American Economic Review 93 (4): 1268-1290. 
Bernard, Andrew B., Marco Grazzi, and Chiara Tomasi. 2015. "Intermediaries in International Trade: Products and Destinations." Review of Economics and Statistics 97 (4): 916-920.

Bernard, Andrew B, J. Bradford Jensen, Stephen J. Redding, and Peter K. Schott. 2007a. "Firms in International Trade." Journal of Economic Perspectives 21(3): 105-130.

Bernard, Andrew B., J. Bradford Jensen, Stephen J. Redding, and Peter K. Schott. 2012. "The Empirics of Firm Heterogeneity and International Trade." Annual Review of Economics 4: 283-313.

Bernard, Andrew B., Stephen J. Redding, Peter K. Schott. 2007b. "Comparative Advantage and Heterogeneous Firms." Review of Economic Studies 74: 31-66.

Blonigen, Bruce. 2008. "New Evidence on Trade Policy Preferences.” Working Paper No. 14,627. NBER

Blonigen, Bruce. 2011. "Revisiting the Evidence on Trade Policy Preferences.”Journal of International Economics 85 (1): 129-135.

Bombardini, Matilde. 2008. "Firm Heterogeneity and Lobby Participation." Journal of International Economics 75: 329-348.

Bombardini, Matilde and Francesco Trebbi. 2012. "Competition and Political Organization: Together or Alone in Lobbying for Trade Policy?” Journal of International Economics 87 (1): 18-26.

Chang, Pao-Li and Gerald Willmann. 2006. "Protection for Sale with Heterogeneous Interests within Industries." Manuscript.

Gawande, Kishore and Usree Bandyopadhyay. 2000. "Is Protection for Sale? Evidence on the Grossman-Helpman Theory of Endogenous Protection." The Review of Economics and Statistics 82 (1): 139-152.

Gawande, Kishore and Bernard Hoekman. 2006. "Lobbying and Agricultural Trade Policy in the United States.” International Organization 60 (3): 527-661.

Goldberg, Pinelopi Koujianou and Giovanni Maggi. 1999. "Protection for Sale: An Empirical Investigation." The American Economic Review 89 (5): 1135-1155.

Gilligan, Michael J. 1997. "Lobbying as a Private Good with Intra-Industry Trade." International Studies Quarterly 41: 455-474.

Grossman, Gene M. and Elhanan Helpman. 1994. “Protection for Sale.” American Economic Review 84 (4): 833-850.

Guisinger, Alexandra. 2009. "Determining Trade Policy: Do Voters Hold Politicians Accountable?" International Organization 63 (2): 533-557.

Hainmueller, Jens and Michael J. Hiscox. 2006. "Learning to Love Globalization: Education and Individual Attitudes Toward International Trade.” International Organization 60: 469-498.

Hayakawa, Kazunobu, Tomohiro Machikita, and Fukunari Kimura. 2012. "Globalization and Productivity: A Survey of Firm-level Analysis.” Journal of Economic Surveys 26 (2): 332-350.

Head, Keith and John Ries. 2003. "Heterogeneity and the FDI versus Export Decision of Japanese Manufacturers." Journal of Japanese and International Economies 17: 448-467.

Helpman, Elhanan, Oleg Itskhoki, and Stephen Redding. 2010. "Unequal Effects of Trade on Workers with Different Abilities." Journal of the European Economic Association 8 (2-3): 421-433.

Helpman, Elhanan, Marc Melitz, and Stephen Yeaple. 2004. "Export Versus FDI with Heterogeneous Firms.” American Economic Review 94 (1): 300-316.

Hiscox, Michael. 2001. "Class versus Industry Cleavages: Inter-Industry Factor Mobility \& the Politics of Trade." Industrial Organization 55 (1): 1-46.

Hiscox, Michael. 2002. "Commerce, Coalitions and Factor Mobility." American Political Science Review 96 (3): 593-608. 
Japan Small Business Research Institute. 2010. White Paper on Small and Medium Enterprises in Japan: Pulling Through the Crisis.

Jensen, J. Bradford, Dennis P. Quinn, and Stephen Weymouth. 2015. "The Influence of Firm Global Supply Chains and Foreign Currency Undervaluations on U.S. Trade Disputes." International Organization 69 (4): 913.

Johns, Leslie and Rachel L. Wellhausen. 2016. "Under One Roof: Supply Chains and the Protection of Foreign Investment." American Political Science Review 110 (1): 31-51.

Kasahara, Hiroyuki and Beverly Lapham. 2013. "Productivity and the Decision to Import and Export: Theory and Evidence." Journal of International Economics 89 (2): 297-316.

Kim, In Song. 2016. "Political Cleavages within Industry: Firm Level Lobbying for Trade Liberalization." Manuscript.

Kim, In Song, Helen V. Milner, Thomas Bernauer, Gabriele Spilker, lain Osgood, and Dustin Tingley. 2016. "Firms' Preferences over Multidimensional Trade Policies: Global Production Chains, Investment Protection and Dispute Settlement Mechanisms." Manuscript.

Kimura, Fukunari and Kozo Kiyota. 2006. "Exports, FDI, and Productivity: Dynamic Evidence from Japanese Firms." Review of World Economics 142 (4): 695-719.

Kiyota, Kozo and Shujiro Urata. 2008. "The Role of Multinational Firms in International Trade: The Case of Japan." Japan and the World Economy 20 (3): 338-352.

Kuno, Arata and Megumi Naoi. 2015. "Framing Business Interests: How Campaigns Affect Firms' Positions on Preferential Trade Agreements." Manuscript.

Kuo, Jason. 2011. "Favoring International Trade for Profits: Survey Evidence from Four Asia-Pacific Countries." Manuscript.

Madeira, Mary Anne. 2013. "The New Politics of the New Trade: The Political Economy of IntraIndustry Trade." PhD Dissertation, University of Washington.

Mansfield, Edward D. and Diana C. Mutz. 2009. "Support for free trade: Self-interest, sociotropic politics, and out-group anxiety" International Organization 63 (3): 425-457.

Mayda, Anna Maria and Dani Rodrik. 2005. "Why are Some People (and Countries) More Protectionist than Others?" European Economic Review 49: 1393-1430.

Melitz, Marc J. 2003. "The Impact of Trade on Intra-Industry Reallocations and Aggregate Industry Productivity." Econometrica 71 (6): 1695-1725.

Melitz, Marc J. and Gianmarco IP Ottaviano. 2008. "Market Size, Trade, and Productivity." Review of Economic Studies 75 (1): 295-316.

Milner, Helen. 1988. Resisting Protectionism: Global Industries and the Politics of International Trade. Princeton, NJ: Princeton University Press.

Nadeau, Richard, Richard G. Niemi, David P. Fan, and Timothy Amato. 1999. "Elite Economic Forecasts, Economic News, Mass Economic Judgments, and Presidential Approval." The Journal of Politics 61 (1): 109-135.

Naoi, Megumi and Ikuo Kume. 2011. "Explaining Mass Support for Agricultural Protectionism: Evidence from a Survey Experiment During the Great Recession." International Organization 65 (4): 771-795.

Osgood, lain. 2016. "Differentiated Products, Divided Industries: Firms and the Politics of IntraIndustry Trade." Economics and Politics forthcoming.

Osgood, lain, Dustin Tingley, In Song Kim, Thomas Bernauer, Helen V. Milner, and Gabrielle Spilker. 2016. "The Charmed Life of Superstar Exporters: Firms and Trade Policy in Costa Rica." Journal of Politics forthcoming. 
Plouffe, Michael. 23 October 2011. "Firms and Foreign Market Engagement: Internationalization Activities among Japanese Firms." Manuscript presented at the meeting of the Japan Society of International Economics, Tokyo.

Plouffe, Michael. 2012. "Liberalization for Sale: Heterogeneous Firms and Lobbying over FTAs." Manuscript prepared for the meeting of the American Political Science Association, New Orleans, Louisiana.

Plouffe, Michael. 2013. 'The New Political Economy of Trade: Heterogeneous Firms and Trade Policy.' PhD Dissertaiton, UC San Diego.

Plouffe, Michael. 2015. "Heterogeneous Firms and Policy Preferences." In The Oxford Handbook of the Political Economy of International Trade, edited by Lisa Martin. Oxford: Oxford University Press. 196-212.

Rogowski, Ronald. 1987. "Political Cleavages and Changing Exposure to Trade.” American Political Science Review 81 (4): 1121-1137.

Roh, Sungmin and Michael Tomz. 2015. “Industry, Self-Interest, and Individual Preferences over Trade Policy." Manuscript.

Scheve, Kenneth and Matthew J. Slaughter. 2001. "What Determines Individual Trade-Policy Preferences?" Journal of International Economics 54 (2): 267-292.

Şeker, Murat. 2012. "Importing, Exporting, and Innovation in Developing Countries." Review of International Economics 20 (2): 299-314.

Tomiura, Eiichi. 2007. "Foreign Outsourcing, Exporting, and FDI: A Productivity Comparison at the Firm Level." Journal of International Economics 72 (1): 113-127.

Tomiura, Eiichi, Banri Ito, and Ryuhei Wakasugi. 2011. "Offshore Outsourcing Decision and Capital Intensity: Firm-Level Relationships.” Economic Inquiry 49 (2): 364-378.

Wakasugi, Ryuhei and Ayumu Tanaka. 2012. "Firm Heterogeneity and Internationalization: Evidence from Japanese Firms." Millennial Asia 3 (1): 45-70.

Woll, Cornelia. 2008. Firm Interests: How Governments Shape Business Lobbying on Global Trade. Ithaca, NY: Cornell University Press.

Wooldridge, Jeffrey M. 2009. "On Estimating Firm-Level Production Functions Using Proxy Variables to Control for Unobservables." Economics Letters 104: 112-114.

Yeaple, Stephen R. 2005. “A Simple Model of Firm Heterogeneity, International Trade, and Wages.” Journal of International Economics 61 (1): 1-20. 